This is the accepted version of the article published in:

(2017) 2(1) China Law and Society, 1-62

\title{
Detention and Its Reforms in the PRC
}

Sarah Biddulph*, Elisa Nesossi*, Flora Sapio and Susan Trevaskes

\begin{abstract}
This article reviews forms of detention and their reforms in the People's Republic of China (PRC). We examine the changing scope and uses of both administrative and criminal detention powers in the reform period and the impact of changing politics, ideology, and law in reform of both detention powers and institutions.
\end{abstract}

In Part 1, we focus on the continuities and discontinuities in the ideology of punishment, the perceived role and uses of detention in shaping society and in social control. In Part 2, we explore the factors relevant to the reform or abolition of range of administrative detention powers. We seek to understand how reforms have occurred, where they have stalled and where they are now possible. We ask how relevant these considerations are to the reform of criminal detention powers and find some distinctive features, not least of which is the comparative rigidity brought about by legal codification. We also note that reform to some administrative detention powers has been accompanied by an expansion in the criminal justice system.

\section{Introduction}

Virtually all governments use deprivation of liberty in various ways to regulate and shape human behavior and to promote their own social, political, and economic goals. Since formation of the People's Republic of China (PRC) in 1949, Chinese authorities have used deprivation of liberty to control and punish those who engage in crime, dissent, and other conduct that the Party-state deems unacceptable. Indeed, since then Chinese authorities have considered the deprivation of liberty central to the political ambitions of socialism. Deprivation of liberty thus plays a much broader role than simply punishing or reforming people for individual transgressions. It is used to assert and strengthen political control, to effect social transformation, stigmatize certain groups and signal social, economic, and political values. In the PRC, deprivation of liberty continues to be used as a political tool to advance socialism "with Chinese characteristics." Alongside market reforms, the Party-state has also re-formed deprivation of liberty in concept and in practice in service of its goal of social stability.

This article explores not only the what question, in describing forms of detention, but also how reform of law and policy relating to deprivation of liberty has been effected and why. In official Chinese discourse, "reform" [gaige] refers to change but does not necessarily connote improvement, as it does in English. In the context of governance in the PRC, gaige means literally to re-form: adjusting existing practice and law to fit current governance programs and political discourse.

In Part 1 of this article, we explore the changing political rationales for detention and punishment. We begin with a discussion of Maoist concepts of thought reform and the theory of contradictions to better understand the genesis and continuity of thinking in the Maoist and reform eras.. ${ }^{1}$ Our main argument is that, although understandings of deprivation of liberty have their roots in Marxist-Maoist political philosophy, in the reform era these have been progressively retailored to suit the Party-state's political

${ }^{1}$ In this article, we refer to the reform era as the period commencing with the communiqué adopted at the third plenary session of the eleventh Central Committee of the Chinese Communist Party in December 1978, which embrace a policy of economic reform and opening up to the outside world. The period we refer to as the Maoist period extends from the establishment of the PRC in 1949 until the start of the reform era in December 1978. 
and practical needs for social management in a "socialist market economy." Deprivation of liberty has been recast both in concept and in practice to maintain its utility as an effective regulatory instrument in a period of pervasive socioeconomic and political transformation that, in turn, has produced new problems of crime and other forms of behavior deemed antisocial and unacceptable by the Party-state. The practical utility, ideological adaptability, and discursive versatility of deprivation of liberty make it a useful tool.

In Part 1 we also consider the increasingly significant role of law in regulating detention in the reform era. We argue that law has played an important role in the reorganization and abolition of some detention powers. Law is one area in which negotiations among state agencies about the balance of institutional power and interests is played out. It is also an arena that permits a range of other voices and interests to be expressed. For example, failure to obtain a consensus to pass laws to authorize administrative detention powers-such as shourong qiansong [detention for repatriation, or custody and repatriation] and laodong jiaoyang [re-education through labor] or laojiao (discussed below)—has been a factor in their ultimate abolition. However, law has not been an unequivocal force for the better protection of detainees' rights. Legal entrenchment of certain forms of detention, such as residential surveillance, have expanded the powers of incommunicado detention, which are now harder to change because of their legal form. The legal definitions of the targets of and procedures for use of detention powers continue to be relatively vague. Further, poor enforcement of legal protections also remains a significant issue. Those who had hoped to see progressive improvement in the law's protection of rights against arbitrary detention and cruel treatment as abuses in various forms of detention have been bitterly disappointed.

Our discussion of the law continues in Part 2 with a detailed analysis of the legal prescriptions and silences in the regulation of individual detention powers. In Part 2 we examine the powers to impose detention. We also address issues relating to the management of the various places of detention. The powers and institutions of detention and deprivation of liberty in China are divided into two main regimes: administrative and criminal. Administrative detention powers are exercised by public security (police) and, in some instances, Ministry of Justice officials. They are not subject to the country's criminal code. These powers are used to detain people for what, in other jurisdictions, might be classified as infringements, summary offenses, misdemeanors, or detention to protect a person from harm or to prevent them from harming others. In contrast, the powers to detain-and, if convicted, to punish - through the criminal justice system are codified in the Criminal Law and the Criminal Procedure Law. In Part 2 we explain the scope and uses of both administrative and criminal detention powers, setting out where reforms have occurred, where they have stalled, and where they are now possible.

In Part 2 we go on to consider some broader questions about the factors that influence the reform of detention powers and the relationship between administrative and criminal detention powers. In both administrative and criminal systems of detention, overarching political, institutional, and resource factors play a clear role. However, in the specifics of their evolution and subsequent pressure for reform, administrative powers have a number of distinctive characteristics. They developed in a piecemeal manner, often in response to particular crises (or perceived crises) and remain fragmented. Their continued existence is readily open to challenge because of their clear divergence from emerging requirements of legality and because of systematic and egregious abuse. We propose a set of considerations we consider relevant to the reform of administrative powers and then explore the extent to which these factors are also relevant to the reform of criminal detention powers.

An overall view of detention powers and the relationship between administrative and criminal detention indicates that the abolition of administrative powers has often resulted in the expansion of criminal forms of detention. Abolition of the administrative power of shourong shencha [detention for investigation, or shelter and investigation] alongside a corresponding expansion of the time limits for criminal detention and the scope of arrest is one example.

Political Rationales for Detention and Punishment 
An exploration of the political rationales for detention helps us to assess its functions as well as the conditions that either enable or hinder change in its practice and objectives. This discussion is divided into two periods: the Maoist and reform eras. As the following section shows, they have a degree of continuity, since the reform era does not display a complete departure from Maoist ideology. In fact, Maoist ideas continue to influence rationales for detention; rather, only the scale and focus of detention have changed to suit the needs of economic reform and the shifting socioeconomic and political situation.

Deprivation of liberty played an important role in the Maoist era as a way to consolidate political control, as a tool of class warfare, and as a way of effecting the transformation of both of society at large and individual consciousness. In the reform era, it has again been called into the service of consolidating political power and control, waging warfare against a new class of enemies: those whose conduct undermines economic reform and damages the social fabric. These issues are explored in more detail in the following section.

\section{Rationalizing Deprivation of Liberty in the Maoist Period}

In the Maoist era, the Chinese leadership saw a certain kind of "thinking" as the necessary precondition for correct behavior and as the basis for understanding and embracing Maoist ideology. Deprivation of liberty was designed to educate and reform those identified as miscreants and to transform them into good socialist citizens with correct thinking - to fully realize socialism in the PRC and to protect the socialist regime and its leadership. One of the objectives of the criminal punishment of reform through labor (laodong gaizao, often shortened to laogai) was to bring inconsistent thinking and behavior into conformity with Maoist ideology. It built on the Maoist notion that consciousness is determined by one's work, and so a proletarian consciousness could be cultivated through hard manual labor, whether industrial or agricultural (Bakken 2000, 2005; Dutton 1992, 2005b; Dutton and Xu 1998; Mühlhahn 2009; Seymour and Anderson 1998).

“Thought reform” was therefore a central rationalizing principle of deprivation of liberty carried out in the criminal justice system and in the administrative detention system. Munro (1977a, 1977b) explained that ideas about reforming prisoners' thoughts through deprivation of liberty were consistent with a socialist understanding of the malleability of human thinking that built on a long history of ideas about the perfectibility of humankind and Leninist ideas on the transformation of humanity under socialism. That understanding saw the human being as highly pliable. The thinking of a prisoner or detainee could be reformed through re-education, often through first-hand experience of collective labor. The mission of reforming prisoners through labor was conceptually part of the broader re-education process operating in society at large and linked to a perceived "fosterage" role of the Party-state in effecting the socialist transformation of society. The process was thus based on the assumption that, once reformed in thought, a person would have a "prompting to act" consistent with that newly acquired consciousness (Munro 1977a, 1977b). Studies such as Bakken (2000, 2005), Dutton (1992), Kiely (2014), and Mühlhahn (2009) provide rich historical detail of this process.

The rationale was conceptually grounded in Mao's theory of contradictions, distinguishing between criminal punishment for those identified as "enemies" (who deserved punishment and repression) and administrative punishment for those identified as the "people" (who merited education, rehabilitation, and reform). On this basis, Mao's strategy was to “divide and break up” criminal gangs to create separate punishment regimes for "the people" and their enemies. The authorities were encouraged to treat the majority with leniency because it was considered part of "the people," whose social conflicts or misdemeanors could be regarded as non-antagonistic contradictions. But the minority of offenders, who were characterized as serious criminals, should be recognized as enemies of the people. Their actions were seen to reflect antagonistic contradictions, and so these criminals needed to be isolated and punished (Keith 1994, 154-55).

From the outset, one of the ways in which the victorious CCP sought to consolidate political control was through use of a range of powers to deprive people of their liberty. The power that was used most often was reform through labor, complemented by a range of administrative detention powers designed to address less serious social problems, deal with those considered politically unreliable, and underpin the 
national development model (in the early days, a Soviet model of taxing agriculture to pay for industrial development). Beginning in 1949, itinerants, vagrants, and beggars in urban areas were put in variously named labor production and education centers. Prostitutes were rounded up and placed in detention to be re-educated and acquire the practical and ideological skills for the new socialist society, and pimps and brothel owners were imprisoned (Biddulph 2007a, 2007b; Dutton 2005; Henriot 1995; Herschatter 1997; Ma 1993). Where opium use was extensive, drug-dependent people were sent to drug detoxification centers [jieyansuo] to give up their "evil habit" (Biddulph 2007a). The privileging of urban, industrial development produced the system of household registration [hukou] designed to prevent the uncontrolled movement of rural migrants to urban areas; those who did not fit into this image or conform to the new socialist ethics were gathered up and put in various forms of detention including prisons (Dutton 2005; Dutton and Xu 2005).

The use of detention as a tool for social transformation and political control was inconsistent during the Maoist era. Swings in the extent and the ferocity with which detention was used followed the vagaries of changing social policy and political campaigns. The use of administrative powers such as reeducation through labor expanded and contracted depending on the political environment-at times with principles of leniency prevailing and at other times political campaigns resulting in the massive expansion of camps and detainees. During the Cultural Revolution (1966-76), many forms of detention withered or were torn down as part of the attacks on and dismantling of institutionalized instruments of governance (Dutton 1992; Mühlhahn 2009).

As to why detention was used, the vicissitudes of revolutionary political campaigns a cross the Maoist era blurred boundaries between repression, reform, and education. This eroded both the theoretical and practical distinctions between criminal and administrative detention. As we discuss below, the Maoist distinction between non-antagonistic contradictions, among the people, and antagonistic contradictions, between the people and their enemies, remains a touchstone of criminal justice policy and therefore at the heart of the concept and the practice of the deprivation of liberty in contemporary China (Trevaskes 2016).

\section{Rationalizing Deprivation of Liberty in the Reform Era}

When it embraced a program of market-based economic reforms and opening to the outside world that was to be institutionalized in part by a new socialist rule of law, the Party-state required the Chinese people to embrace new "thinking." This new thinking now required people to produce, buy, and sell in the market to meet personal as well as collective needs (such behavior was itself a crime in the Maoist era and subject to thought reform, re-education, and punishment). Deprivation of liberty was again called upon as one of the mechanisms to support the changes required to both mentality and conductthat is, to punish conduct harmful to economic and social reforms and to promote and protect China's modernization drive. The ideological and practical dislocation created by introducing market reforms not only required citizens to demonstrate new types of behavior and accept this new thinking but also changed the nature of crime.

On the one hand, the economic reforms opened the way for new types of crime, such as property offenses, to emerge and for the scale of crime to balloon, as well as creating the conditions that facilitated the upsurge in old types of crime and offending. The changed socioeconomic and political conditions of the reform agenda created the capacity, personal will, and, to some extent, the reasons for criminal action. Economic reforms led to partial deregulation of the country's economic life and, to some extent, its political life (Trevaskes 2010). But the state's withdrawal from being the exclusive supplier of goods, services, jobs, income, housing and social services weakened the existing mechanisms of social control, such as the work-unit and the local residential committees (Tanner 200o). The old "social evils" of drug use and dependence, prostitution, pornography, gambling, using what has been labelled "feudal superstition" to deceive the people, and the kidnapping and selling women and children were identified, and the resurgence of these forms of proscribed conduct ignited old fears of corruption of the social fabric and socialist ethics. In theory, economic reforms gave the people the capacity to engage in the market through monetary exchange, as well as the freedom to buy, sell, produce, move, take risks, make profits, and consume outside the state plan. However, in areas where establishing market conditions proved more difficult, especially in rural areas, poverty and fulfilling basic needs 
became drivers of crime and other conduct viewed by the Party-state as socially undesirable. Under these conditions, crime and vice came to be seen by the people not just as a means to acquire wealth but, for some, as simply a means to survive. The weakening of existing mechanisms of social control, which started during the Cultural Revolution, accelerated during the reform era.

On the other hand, the social, economic, and political conditions ushered in by reform also changed the Party-state's perception of crime and interest in responding to it. The priority placed on economic growth through the development of the market meant that the disruption of social order and conduct that harmed the market and market development became new categories of crimes. Crime needed to be addressed to protect economic as well as social and political stability. But the identified need not to impede market development restricted the types of strategies the Party-state was willing and able to adopt both to achieve its objectives and to overcome impediments. Rather than creating and enforcing regulations on market-based activity that might have also impeded market development, the Partystate's preferred strategy was to control and deter crime through severe campaign-style punishments with large doses of detention and imprisonment (Trevaskes 2010).

A number of contradictory trends in the exercise of coercive power emerged. The principle of equality before the law turned attention to punishing offending conduct, rather than punishing a person because of their political designation as a class enemy. But even though class struggle was no longer the central preoccupation of politics, the Maoist approach of distinguishing contradictions between the people and the enemy from contradictions among the people continued to be influential in punishing offenders. Criminal offenders, particularly those whose crimes undermined the economic order, were identified as the new enemy and became the subject of the full weight of the Party-state's repressive powers through the expanding use of incarceration and the death penalty (Trevaskes 2010). Administrative forms of detention were, in theory at least, for use in educating, persuading, and transforming people who continued to be within the bounds of "the people" even though they had transgressed. But the impact of campaigns led to an expansion in the number of people detained under both administrative and criminal forms of detention. The expanding use of administrative forms of detention during campaigns also blurred the boundary between criminal and administrative detention. Theory parroted the assertion that social stigma attached to criminal detention, not administrative detention. However, in practice, no such distinction existed. The social stigma attached to a person detained under laogai in the criminal justice system or laojiao in the administrative system was the same (Biddulph 2007a; for a contrary view, see Peerenboom 2003). These forms of punishment were twinned in the shorthand expression liang lao [the two forms of labor detention].

The ideological retreat from class struggle (and suppression of counterrevolutionaries) at the beginning of the reform era thus reduced the number of but did not eliminate "enemies of the people." In particular, beginning with the first Strike Hard anti-crime campaign in August 1983, the Strike Hard criminal justice policy identified several categories of offenders under the new Criminal Law and Criminal Procedure Law (both passed in 1979) as the new people's enemy and deserving of the full force of state violence that the Strike Hard ethos embodied. The Maoist understanding of the need to identify, classify, and punish crime on the basis of distinguishing between the people and the enemy continued to inform choices about the appropriate approach to deal with transgressions (Biddulph 2007a; Tanner 2000; 2005; Trevaskes 2007).

In this way, the post-Mao Party-state readjusted its key punishment rationale to support the overall national modernization and reform agenda. Deprivation of liberty through incarceration was still justified as a way to protect society from offenders, by isolating these offenders from the community and rehabilitating them through labor, education, and training. The expansion of administrative forms of detention in the 1980 os both represented the Party-state's inability to control the "social evils" using less punitive measures and reflected the impacts of repeated Strike Hard campaigns to punish not only crime but also conduct seen as harming the social fabric. What the Party-state changed was its assessment of the nature of some of the behaviors now identified as criminal or as harmful. In a departure from the Maoist period when people were targeted because of their status or background, in the reform era behaviors were criminalized because they threatened social or political stability or undermined the success of economic reform. 
Another core shift in the reform era was the decisive embrace of socialist legal reform. Since late 1979, law has served to institutionalize state power, both to authorize and to constrain, to allocate powers and responsibilities among state agencies and to separate the Party from the day-to-day administration of economic reform programs. Over time, the ideology of rule of law has been invested with governance values such as fairness (including procedural fairness), justice, and equality, even though very imperfectly realized. In 2004, the constitution was amended to guarantee state protection of and respect for human rights. These values have created both practical and rhetorical tools to support calls for reform or the abolition of detention powers and placed pressure on state agencies to obtain legal authorization for the exercise of their powers. Legislation thus has gradually emerged as an arena in which competing institutional interests are contested and resolved and principles such as statecentered or people-centered governance are balanced and formed. Institutions with the power to detain had to negotiate their roles and responsibilities in the context of these new narratives, which at least in part meant that their powers would need to be authorized and circumscribed by law (Biddulph $2007 \mathrm{a}$ ).

Passage of the Criminal Law and Criminal Procedure Law in 1979 provided the first legal codification of criminal powers and the comprehensive legal basis for imposing not just terms of imprisonment and criminal detention but also noncustodial community-based sentences. Significantly, the definition of detention powers in the Criminal Law (criminal punishments) (Editorial Committee 1996) and in the Criminal Procedure Law (criminal coercive powers) provided the basis for distinguishing them from administrative powers. The Criminal Procedure Law-significantly revised in 1996 and in 2012provided the basic guidelines for implementing the Criminal Law. Most notably, it defined procedures, time limits, and the agencies responsible for carrying out pre- and post-trial procedures. It set out several coercive measures [qiangzhi cuoshi] that could be used to limit the freedom of action of criminal suspects. It also provided for pre-trial detention and imprisonment following conviction. Pretrial coercive measures include coercive summons [juchuan], taking a guarantee and awaiting trial [also translated as bail; [qubao houshen], supervised residence [also translated as residential surveillance; [jianshi juzhu], pre-arrest detention [juliu], and arrest [daibu]. Each of these coercive measures involves the restriction or deprivation of personal liberty.

Administrative detention powers were similarly affected. In the 1980s, many administrative powers were defined primarily by documents issued by the Ministry of Public Security (MPS). This practice became increasingly open to challenge as the requirements for legality, "governing the nation according to the law" [yifa zhiguo] and "administration according to law" [yifa xingzheng], took specific legislative shape. The first challenge came from the Administrative Litigation Law of 1989 (which took effect in October 1990), which required agencies to demonstrate the lawfulness of their administrative decisionmaking. For the first time, the rhetoric of lawfulness acquired specific meaning. The legal problem this created with respect to most police administrative detention powers was that the laws needed to authorize the imposition of these forms of detention did not exist. Despite concerted efforts to draft legislation to provide the legal basis for their powers, the police found it difficult to obtain the consensus necessary for passage of these laws. Shourong shencha [detention for investigation] was the first of these powers to be abolished, but the police were ultimately successful in having the substance of this detention power incorporated into amendments to the Criminal Procedure Law in 1996.

The next challenge was the Administrative Punishments Law, which set out mandatory procedural requirements for the imposition of an administrative punishment. Although many police detention powers were quickly recategorized as "coercive measures" or as "handling measures" to avoid the restrictions imposed by this law, these detention powers could not ultimately escape the Legislation Law, which required all forms of detention to be authorized by a law passed by the National People's Congress (NPC) or its Standing Committee. These legal reforms left other administrative detention powers vulnerable to claims of illegality (Biddulph 2007a).

Of course, illegality on its own was never going to be sufficient reason for these forms of administrative detention to be abolished. Systemic abuse, periodic scandals over horrifying mistreatment of detainees, and deaths in custody all contributed to an upsurge of domestic and international condemnation of these powers. Shifts in the political, legal, and social landscape have helped reconfigure the use of detention and the nature of detention powers, including the abolition of many of the administrative detention powers carried over from the Maoist to the reform era, as the discussion below shows. 
But lest we paint an excessively optimistic picture of the power of law, it is important to consider both the limits of law in governance and the perverse impacts of certain types of legal codification. The fact that state agencies (as well as legislators, academics, and activists) actively engage in processes of legal reform to rectify deficiencies in the law and practice and to entrench particular allocations of resources and powers does not mean either that the legislation ultimately passed better protects the rights of detainees or that the law is faithfully applied. Sometimes, legal codification institutionalizes powers in forms that create legal permission for abusive practices. The example of "residential surveillance in a designated location" discussed below shows that reform of the Criminal Procedure Law in 2012 authorized the police to hold a wide range of people in incommunicado detention away from the institutional protections of formal places of detention and without effective supervision or control. Once enacted in law, individual detention powers and the allocation of powers among the state agencies involved in justice become fixed and therefore difficult to change. Periodic public exposure of abusive practices, the systematic, extralegal persecution of people seeking to hold the state to the standards of its own laws and even the incessant reforms to laws to correct enforcement problems all demonstrate that practice is far away from the legal text. The paradox of adherence to the ideology of the rule of law is that it facilitates change in some areas at the same time as it hinders change in others. It can also be used to promote reforms in the name of justice and human rights at the same time that the legal form can provide cover for abusive practices.

\section{Reform in Practice: An Overview of Change in Institutional and Legal Arrangements}

In theory, coercion in China is organized as an integrated set of programs and powers of escalating severity. Formal punitive powers, including detention, may be exercised within either the administrative or criminal justice system. Legally, administrative and criminal forms of detention are distinct. As we see in the discussion below, the relationship between administrative and criminal detention powers in practice does not always reflect this neat characterization. However, the theoretical framework is reflected in practice in many areas and is significant in debates about reform and so is set out briefly here.

The "first line of defense" comprises an extensive range of community-based strategies, media campaigns, and education programs that operate both prior to and in tandem with administrative detention powers to shape public notions of civility and acceptable behavior. Ideally, the forms of education and persuasion in the so-called first line of defense pre-empt the need for more coercive techniques of reform through administrative forms of punishment and detention. Administrative detention has been called the "second line of defense" against offending (Biddulph 2007a).

Administrative detention powers sanction those who do not conform to established Party-state authorized norms or whose breaches of the law are minor and repeated or not sufficiently serious to warrant criminal sanction. If administrative sanctions are unsuccessful, then the conceptually more coercive criminal justice system is used to punish offenders.

We might wonder about the effectiveness of this system of interlinked powers to educate, reform, and punish transgression. Regardless of whether authorities remain confident about the capacity of these strategies, campaigns and programs to forestall, reshape, and reform aberrant behavior, they not only continue but in some areas have gradually been expanded. In some cases, such as management of drug users, a clear continuum is seen between behavioral guidance and control and the use of administrative detention. In cases such as drug use and dependency, education gains a more coercive face with registration of drug users by the police, which in turn enables their subsequent monitoring and testing. Registration and testing then allows identification and imposition of compulsory, community-based treatment regimes. Those who continue to use illicit drugs or who fail to comply with compulsory community-based orders can be detained for compulsory drug rehabilitation.

Administrative detention powers are also interlinked and can be applied sequentially. So, for example, the first prostitution-related offense may be punished by a period of administrative detention under the 2006 Public Security Administrative Punishments Law (PSAPL) and the second offense by detention under the power of detention for education [shourong jiaoyu, commonly called shoujiao] or, before its abolition, laojiao. Alternatively, two forms of detention may be imposed for the same conduct. For 
instance, a period of administrative detention [xingzheng juliu] may be followed by detention for education.

The system of administrative detention is run in parallel with the criminal justice system but is organized separately from it. In the criminal justice system, criminal suspects, defendants, and convicted criminals may by law be deprived of their liberty in police stations, pretrial detention centers (before or after arrest), and prisons. They may also be subject to residential surveillance at their domicile, work-unit, or at other locations determined by the public security authorities prior to trial. In effect, they are deprived of their liberty even though not physically detained in an institution.

The legal basis and scope of criminal detention and deprivation of liberty powers are set out in the Criminal Law (criminal punishments) and in the Criminal Procedure Law (criminal coercive powers). Since 1979 codification has provided a legal division between administrative and criminal powers, even if this division is blurred in practice. Examples include the powers such as liuzhi panwen [detention for interrogation] and, before their abolition, shourong shencha [detention for investigation], and liuchang jiuye [retention for in-camp employment]. The first two are primarily used as an adjunct to criminal coercive powers of criminal detention and arrest but are legally characterized as administrative. Liuchang jiuye acted effectively as a supplementary form of criminal punishment, imposed after expiration of a term of incarceration in reform through labor [laogai].

As there are many detention powers, we begin with an overview of the powers themselves. The list is long and potentially confusing, so we use two tables that discuss them in the order in which they are discussed in subsequent sections: Table 1 , which lists administrative detention powers, and Table 2, which lists criminal detention powers. These tables also briefly note the changes in these powers that have taken place over time, with some powers abolished, some substituted with other powers, and some transferred officially or in substance from the administrative system to the criminal justice system. We then discuss administrative detention powers and reforms in the administrative detention system in more detail and afterward turn to reform of detention powers in the criminal justice system. Although in theory liuchang jiuye could be characterized as administrative, we put it in the category of criminal detention powers, as it was used primarily as a supplement to imprisonment.

Table 1. Administrative Detention Powers

\begin{tabular}{|l|l|}
\hline shourong shencha & $\begin{array}{l}\text { Detention for investigation (also called shelter and investigation), for } \\
\text { investigation and interrogation of those suspected of criminal or } \\
\text { counterrevolutionary offenses. Abolished as an administrative power in } 1996 \\
\text { and incorporated into the } 1996 \text { Criminal Procedure Law. }\end{array}$ \\
\hline shourong qiansong & $\begin{array}{l}\text { Detention for repatriation (also called custody and repatriation), for } \\
\text { detention and repatriation of unauthorized rural migrants into cities. } \\
\text { Abolished in } 2003 \text { and replaced by an allegedly noncoercive welfare power } \\
\text { by the State Council Measures on Aiding Vagrants and Beggars Having No } \\
\text { Means of Livelihood in Cities. }\end{array}$ \\
\hline $\begin{array}{l}\text { qiangzhi yiliao } \\
\text { Compulsory treatment of mentally ill people }\end{array}$ \\
\hline $\begin{array}{l}\text { fei ziyuan } \\
\text { zhuyuanzhiliao }\end{array}$ & Compulsory detention and treatment of mentally ill people. \\
\hline
\end{tabular}




\begin{tabular}{|c|c|}
\hline $\begin{array}{l}\text { laodong jiaoyang } \\
\text { (laojiao) }\end{array}$ & $\begin{array}{l}\text { Re-education through labor, used for a wide range of minor offending and } \\
\text { extending to cover general trouble-making conduct (including repeat and } \\
\text { nuisance petitioners) or political dissent (abolished December 2013). }\end{array}$ \\
\hline qiangzhi jiedu & $\begin{array}{l}\text { Coercive drug rehabilitation, for detention of drug-dependent people in } \\
\text { police-run detention centers for between three and six months with a } \\
\text { possible extension of up to one year. Abolished in } 2008 \text { with passage of the } \\
\text { Drug Prohibition Law. }\end{array}$ \\
\hline qiangzhi geli jiedu & $\begin{array}{l}\text { Coercive quarantine for drug rehabilitation, for detention of drug } \\
\text { dependent people imposed under the Drug Prohibition Law for an initial } \\
\text { period of two years with a possible reduction or extension of one year (thus } \\
\text { between one and three years). Detention of drug-dependent people in } \\
\text { laojiao and coercive drug rehabilitation were abolished and consolidated } \\
\text { within this power upon passage of the } 2008 \text { Drug Prohibition Law. }\end{array}$ \\
\hline $\begin{array}{l}\text { shourong jiaoyu } \\
\text { (shoujiao) }\end{array}$ & $\begin{array}{l}\text { Detention for education, for education of sex workers and their clients } \\
\text { under the Decision on Strictly Prohibiting Prostitution and Using } \\
\text { Prostitutes (which also allows coercive testing and treatment for sexually } \\
\text { transmitted infections [STIs], and coercive treatment). }\end{array}$ \\
\hline qiangzhi yiliao & $\begin{array}{l}\text { Compulsory testing and treatment, for STIs and HIV under laws including } \\
1991 \text { Decision on Strictly Prohibiting Prostitution and Using Prostitutes and } \\
\text { the } 2008 \text { Drug Prohibition Law. }\end{array}$ \\
\hline shourong jiaoyang & $\begin{array}{l}\text { Detention for re-education, for punishment, rehabilitation or putatively for } \\
\text { (re)education of juveniles committing minor offenses or who otherwise fall } \\
\text { outside the jurisdiction of the criminal justice system. }\end{array}$ \\
\hline shuanggui & $\begin{array}{l}\text { An investigative detention measure, used by Party discipline organs against } \\
\text { members of the CCP suspected of criminal offenses, corruption, or } \\
\text { misconduct. As a measure used by the Party, this measure does not squarely } \\
\text { fall within the state legal system. }\end{array}$ \\
\hline xingzheng juliu & $\begin{array}{l}\text { Administrative detention, imposed under the } 2006 \text { Public Security } \\
\text { Administrative Punishments Law (as amended in 2012). }\end{array}$ \\
\hline liuzhi panwen & $\begin{array}{l}\text { Detention under the } 1995 \text { People's Police Law (as amended in 2012), for an } \\
\text { initial period of twenty-four hours and no more than forty-eight hours in } \\
\text { the police station for interrogation in relation to suspected offenses. }\end{array}$ \\
\hline
\end{tabular}

Table 2. Criminal Detention Powers

\begin{tabular}{|l|l|}
\hline xingshi juliu & $\begin{array}{l}\text { Pre-arrest criminal detention. A police investigatory power. Allows a } \\
\text { period of up to thirty-seven days' initial detention without warrant } \\
\text { and without notification to a suspect's family or work-unit in cases } \\
\text { of crimes against state security or terrorism. Based on the Criminal } \\
\text { Procedure Law 2012 (Article 80). }\end{array}$ \\
\hline daibu & $\begin{array}{l}\text { Arrest (and detention pending trial). Approved by the } \\
\text { procuratorate, or less frequently, the court on application by the } \\
\text { police. Based on the Criminal Procedure Law 2ol2 (Article 79). }\end{array}$ \\
\hline jianshe juzhu & $\begin{array}{l}\text { Residential surveillance and residential surveillance in a designated } \\
\text { location. Residential surveillance can last for a maximum of six } \\
\text { months, and it is used on ordinary offenders. Residential } \\
\text { surveillance at a designated location has the same maximum } \\
\text { duration, and it is used for those without a fixed abode, suspects of } \\
\text { crimes against state security, terrorism, and grave crimes of } \\
\text { corruption. Both measures are based on the Criminal Procedure } \\
\text { Law 2o12. }\end{array}$ \\
\hline juyi & $\begin{array}{l}\text { Punishment of criminal detention. Between one and six months' } \\
\text { imprisonment, used as a punishment for those convicted of criminal } \\
\text { offenses resulting in a minor degree of social harm. Based on the } \\
\text { Criminal Law 1997. }\end{array}$ \\
\hline
\end{tabular}




\begin{tabular}{|l|l|}
\hline youqi tuxing, wuqi tuxing & $\begin{array}{l}\text { Punishment of imprisonment, based on the Criminal Law 1997, it } \\
\text { has a minimum duration of six months' imprisonment and a } \\
\text { maximum of fifteen years. A term of imprisonment is served in } \\
\text { facilities where convicted offenders are required to perform manual } \\
\text { labor and to undergo ideological education. Life imprisonment is a } \\
\text { term of fifteen to twenty years or more. }\end{array}$ \\
\hline liuchang jiuye & $\begin{array}{l}\text { Retention for in-camp employment. This measure was originally } \\
\text { used to prevent release of criminal convicts after their terms of } \\
\text { imprisonment were complete. Its use was phased out after passage } \\
\text { of the Prison Law in 1994. }\end{array}$ \\
\hline $\begin{array}{l}\text { qiangzhi yiliao, fei ziyuan } \\
\text { zhuyuan zhiliao }\end{array}$ & $\begin{array}{l}\text { Compulsory treatment and involuntary hospitalization on the } \\
\text { grounds of mental incompetence. These are based on the Criminal } \\
\text { Procedure Law } 2012 \text { and on the Mental Health Law 2012. }\end{array}$ \\
\hline
\end{tabular}

Some important questions arise. First, what has been the impact of abolition of some administrative detention powers, and how has this affected the balance between administrative and criminal forms of detention and the overall scope of detention powers? Second, what factors drive or enable reform, and are they the same for administrative and criminal powers, or are different forces at play in reform of administrative and criminal forms of detention? We explore these questions in this section.

\section{Reform of Administrative Detention Powers}

At the beginning of the reform era, many administrative powers were in use. They had evolved as ad hoc and fragmented responses to political needs and social problems. Administrative powers were a flexible tool for social control. They had the capacity to be altered in response to emerging social order problems that arose out of the social and economic dislocation brought about by the reform policies and the corresponding breakdown of social control mechanisms. The foundations of these social control systems that had depended upon the disciplinary role of the work-unit and a static and transparent population created by the system of household registration weakened and gradually collapsed as economic reforms progressed. Their flexibility made administrative powers attractive to the police and the Party-state, but it was precisely this characteristic that enabled not only their expansion but also their widespread and systematic abuse. As the legal system grew, administrative detention powers came to symbolize the antithesis of legal ideals of governance constrained by law, proportionality, accountability, and fairness. Instead of solving social problems, they increasingly came to be seen as and actually became complicit in causing social problems. Since the beginning of the reform period, widespread debates have been waged about how to reform and whether to abolish these administrative powers. Some, including shourong shencha, shourong qiansong, qiangzhi yiliao, feiziyuan zhuyuan zhiliao, and laojiao have already been radically transformed or abolished. Others, such as shourong jiiaoyu, may soon be abolished.

The processes of critique and reform of administrative detention powers, such as shourong shencha, shourong qiansong, and laojiao, and, to a lesser extent, powers to detain and impose involuntary treatment on mentally ill people, share a number of characteristics. In fact, the similarities are strong enough to suggest a pattern in the reform of these administrative detention powers. This can be summarized in the following steps.

- Use of the power is expanded to include a range of people and activities that fall well outside the original scope and intent of the power.

- Egregious and systematic abuse of the power, sometimes with one or several highly publicized incidents, brings the administrative power increasingly into the public spotlight and galvanizes critical public, academic, and official attention. International criticism and advocacy are focused on reforming or abolishing the power.

- The way in which the power is used lacks the requisite legal justification and is subject to criticism that it is unlawful, disproportionate, and unconstitutional. The public security bureaus and other justice departments are unable to obtain the consensus necessary to draft and pass the legislation necessary to reform and preserve the power. 
Biddulph (2016) suggests that three considerations are central to the ultimate decision to abolish these forms of detention. First, is there popular and international criticism of the power such that it can be abolished in a way that is politically advantageous or at least not disadvantageous? Second, can the power be abolished in a way that does not have a significant impact on public order? Finally, is there an alternative form of punishment available, or has a decision been reached that the targeted conduct no longer needs to be punished or controlled?

Reform is inevitably carried out in a way that deals with the specific problem. But, to date, reforms have not been carried out in a way that addresses the broader issues debated prior to abolition of the particular power, such as the minimum requirements to conform with principles of constitutionality or with rule of law, the orientation of governance as people centered or state centered, or the vision of justice embedded in use of such detention powers and in the legal system more generally. ${ }^{2}$. In the next section, we consider how well these factors help to explain drivers and constraints on reform of criminal detention powers as well. We suggest that many are relevant but that the codification of both criminal punishments and coercive measures distinguishes them from administrative powers and limits the scope and opportunities for reform to more formal and highly contested legislative reform processes.

Below is a brief description of the scope and fate of the main administrative detention powers. We first discuss those that have been abolished or significantly reformed. The power to detain the mentally ill falls into a twilight zone between the criminal and administrative systems, with some aspects transferred to the criminal justice system, and so it is discussed both here and in the section on criminal justice. We then turn to administrative powers that remain under the heading "Reforming the Remaining Administrative Detention Powers?"

\section{Shourong shencha [Detention for Investigation]}

This form of detention emerged in the 1950s as a way of penalizing and discouraging the uncontrolled movement of rural workers to urban areas. In 1957 the Central Committee of the CCP and the State Council instructed that shourong shencha was to be used to detain unauthorized rural migrants and beggars to be repatriated (Directive on Preventing the Blind Outflow of the Rural Population [Ganyu zhizhi nongcun renkou mangmu wailiu de zhishi]). "Troublemakers" among these migrants and beggars were supposed to be identified and sent to laojiao or subjected to a criminal punishment. This form of detention was used initially to hold unauthorized migrants who had been gathered for repatriation and for investigation and punishment. Use of this power expanded dramatically after 1961, as the massive starvation resulting from the Great Leap Forward led to huge population displacement (Biddulph 2007a).

After 1975, this detention power was split, with detention for the repatriation of unauthorized migrants shifted to another detention power, shourong qiansong (discussed below). Beginning at this time, shourong shencha was intended to be used for investigation and interrogation of those suspected of criminal or counterrevolutionary offenses. Its use was expanded after the first Strike Hard anti-crime campaign offensive in 1983, to detain for interrogation people suspected of going from place to place committing crime but whose identity could not be confirmed. In time, shourong shencha evolved into a power that the police used commonly as a substitute for the more restrictive criminal investigation power of criminal detention. As the use of shourong shencha was not subject to effective oversight, it rapidly evolved into one of the most systematically abused and feared of the police powers. It was finally abolished as a standalone administrative power in 1996. However, it was not entirely abolished, as it was effectively absorbed into the criminal coercive powers of the police exercised under the 1996 revisions to the Criminal Procedure Law by expanding the maximum length of time for the coercive power of criminal detention and reducing the criteria for arrest.

\section{Shourong qiansong [Detention for Repatriation]}

\footnotetext{
${ }^{2}$ On how broader issues were not canvassed in reform/abolition of laojiao, see Fu 20o9; and on shourong qiansong, see Hand 2006-7.
} 
After 1975, shourong qiansong was established as a standalone form of detention operated by the civil authorities for the detention and repatriation of undocumented and unauthorized rural migrants. The police were authorized to send these people to detention centers operated by the civil affairs departments, called detention for repatriation stations [shourong qiansong zhan]. People held in detention centers were required to work, were often held in poor and unsafe conditions, and were often not repatriated but, rather, released after payment or after the official need to "clean up" the city (e.g., a visiting dignitary or a major international event) had passed. Systemic abuses of this power, coupled with dangerous conditions within the detention centers, came to light because of the public scandal that surrounded the beating death of a young migrant worker named Sun Zhigang.

In March 2003, Sun Zhigang was beaten to death while in custody in Guangzhou (Hand 2006-7). Official attempts to cover up the event, denunciations in the media of an obsolete and brutal system used indiscriminately to deprive citizens of their liberty, and the feeling of empowerment brought by the then-recently enacted Legislation Law 2000 paved the way for the issue of detention under shourong qiansong to be added to the public discourse on justice reforms. Three law graduates, $\mathrm{Xu}$ Zhiyong, Teng Biao, and Yu Jiang, wrote to the NPC to demand the abolition of custody and repatriation.

As with other forms of administrative detention, shourong qiansong had been expanded well beyond its intended scope to take in beggars, vagrants, people with mental illness, and other people who disrupted urban tidiness. It was increasingly a focus of critical attention. This detention power had no proper legal justification, and one could not be obtained before shourong qiansong was overwhelmed by the scandal surrounding Sun's death. Because this scandal occurred just as Hu Jintao and Wen Jiabao were seeking to establish their own leadership positions and a different vision of governance that would be people oriented, the time was politically ripe for the system to be abolished (Hand 2006-7). It was officially replaced by a so-called welfare power, run by the civil affairs administration to provide temporary housing and food to itinerants in cities with no other means of support. Little is currently known about how this welfare measure is implemented in practice.

\section{Powers to Detain People with Mental Illness: qiangzhi yiliao and fei ziyuan zhuyuanzhiliao}

Powers to detain people with a mental illness traverse both criminal and administrative systems of detention. After amendments to the Criminal Procedure Law in 2012, a special chapter was inserted on procedures for dealing with people who had committed crime but were mentally incompetent to be held criminally liable for that crime. The power to detain mentally ill criminal offenders was thus converted from an administrative into a criminal procedure. That power is addressed separately in the section below on criminal detention powers. This section addresses administrative forms of detention as they existed until 2012 and recent legal reforms to civil committal.

Endemic misuse of involuntary committal and treatment of people who are not mentally ill but are considered a nuisance or troublemakers, either to their family or politically, has been the subject of sustained international scrutiny and criticism. The most comprehensive work in this area has been conducted by Robin Munro (2000, 2007) (see also Human Rights Watch and Geneva Initiative on Psychiatry. 2002). The power to detain persons with a mental illness in a psychiatric hospital received a legal basis in Chinese law only in 1987. Following the first National Public Security Conference on the Custody and Treatment of the Mentally Ill, the MPS enacted three internal documents: Measures on the Administration of Ankang Hospitals, Detailed Implementation Rules for Work in Ankang Hospitals, and Rules for Admitting and Treating Mentally Ill Persons Who Seriously Endanger Public Security. ${ }^{3}$. Although these rules are mentioned by Human Rights Watch (2002), researchers have been unable to access their content, due to their secretive nature. From the work of Munro (2000, 2007), however, it is understood that administrative detention in a psychiatric hospital was modeled after the measures used in the Soviet Union. Thus it was used not only for those who committed violent acts as a result of their mental illness but for political dissidents as well. Because of the secretive nature of the regulations as well as of mental health institutions, little was known about the procedural rules on this form of

\footnotetext{
${ }^{3}$ Ankang (in English peace and health) are the psychiatric institutions operated by the Ministry of Public Security. In theory they are used to detain people who have been determined to be criminally insane.
} 
administrative detention, its maximum time limits, the existence of review and remedial mechanisms or alternative measures to detention.

In terms of civil committal, the 2012 Mental Health Law states that, in most circumstances, hospitalization for treatment for mental illness, either as an outpatient or an in-patient, should be voluntary (Articles 3, 5, 27, 30). The exception is when people have a serious mental illness and poses a risk to their own safety or that of others (Articles 28 and 30). Those who have a serious mental illness and pose a risk to themselves but not others may be involuntarily admitted only with the consent of their legal guardian (Article 31). The law also provides for some procedural safeguards in the case of involuntary admission. Both the people and their guardian are entitled to an independent review of the decision (Article 32) and may ask a court to review the case if they find a breach of the specified procedures law (Articles 32 and 82). The law does not specify time limits for the admission of in-patient treatment or for re-evaluation except when the person's "clinical status" changes (Article 44). However, in practice, people with serious mental illness continue to be admitted to a psychiatric hospital involuntarily by family members responsible for that person's care. Although legal protections have improved, some central concepts, such as "serious mental illness" and "posing a risk themselves or others," remain ill-defined, and mechanisms for supervision and accountability are still vague, and so the potential for abuse remains real. But continuing problems and abuse must also be understood in the context of a gross lack of trained mental-health professionals and facilities as well as the continuing reliance on family members for the primary care of people with mental illness.

Laojiao [Re-education through Labor]

Laojiao was officially established in 1955 during the campaign for the suppression of internal counterrevolutionaries, though it had antecedents in the systems of forced labor introduced in 1951 (Biddulph 2007a). Although it started as a power to detain people considered politically unreliable, it rapidly expanded to cover a wide variety of minor offenses. Throughout the Maoist period, laojiao expanded and contracted, first to serve the needs of political campaigns and then to retreat from the worst excesses of those campaigns. Laojiao originally had no time limits, in line with thinking that a person would be released when authorities assessed that the person had been rehabilitated. Only in 1961 was a maximum of three years imposed on laojiao, after the excesses of the anti-rightist movement (Biddulph 2007a).. During the Cultural Revolution, it fell into chaos and relative disuse as did many state institutions (Biddulph 2007a).

Laojiao was revived and expanded after the end of the Cultural Revolution. The December 1979 State Council Notice Promulgating the Temporary Regulations of the Ministry of Public Security on ReEducation through Labor [Guowuyuan zhuanfa gong'an bu "laodong jiaoyang shixing banfa"] defined the scope of targets to cover conduct deemed anti-socialist and conduct harming social order, as well as vice and petty crime. The scope of targets of laojiao was consolidated and expanded in the Temporary Measures on Re-Education through Labor (Temporary Measures), which were approved and issued by the State Council in January 1982.

After the introduction of the open door and economic reform policy, the targets of laojiao increased incrementally to cover newly emerging forms of socially disruptive or unlawful conduct and to respond to newly emerging social problems and political sensitivities (Biddulph 2007a; Chen 2003; Chen et al. 2002; .Fu 2005b; Hung 2003).. Adoption of a piecemeal policing strategy based on anti-crime campaigns, also contributed to the gradual and constant expansion of laojiao targets. Repeat and nuisance petitioning, petty theft, fraud, and other conduct considered anti-socialist or anti-Party could conveniently fall within the amorphous bounds of laojiao. It was therefore a particularly useful and flexible tool for policing dissent and disruptive rights-asserting conduct. For example, during the crackdown on Falungong, beginning in the late 1990s, many practitioners were sent to laojiao for refusing to give up the practice (Biddulph 2007a; Fu 2005b; Human Rights Watch 2002; Sapio 2010.). Repeat petitioners and people involved in mass protests or groups targeted because of religious beliefs and practices, such as Tibetans and Uyghurs, were often sent for a term of laojiao (Fu 2005b; Potter 2003). It was also a convenient way to punish people who criticized Party and government leaders or whose conduct was construed as opposing the state but fell short of the criminal offense of harming national security. Starting in the late 1980s, the largest increase in the number of people sent to laojiao was associated with drugs: drug-dependent people and other drug users (Biddulph and Xie 2011). 
Laojiao also proved useful for police where legal reforms in other areas restricted police investigation and interrogation powers. It was used to enable investigation to continue in situations in which time or evidence was insufficient to proceed with a criminal prosecution, particularly after the police power to detain and interrogate criminal suspects under detention for investigation [shourong shencha, discussed above] was abolished in 1996 (Biddulph 2007a; Fu 2005a).

The Regulations on Public Security Organs Handling Re-Education through Labor Cases (Gong'an jiguan banli laodong jiaoyang anjian guiding), issued by the Ministry of Public Security on June 1, 2002, added further types of conduct to be targeted for laojiao and reframed offenses to correspond more closely with the categories of crime listed in the Criminal Law.. It was the last regulatory consolidation of laojiao targets, although expanding the scope of targets continued on an ad hoc basis afterward (Biddulph 2007a).

In theory, the decision to impose a period of laojiao was made by the Laojiao Management Committee, whose representatives come from justice, public security, civil administration, and community organizations (Biddulph 2007a); but in fact laojiao approval procedure was exercised by the public security organs. The Regulations on Public Security Organs Handling Re-Education through Labor Cases 2002 (as amended in 2005) set out procedures to be followed by the public security organs in investigating and determining the imposition of a period of detention under laojiao, exercised primarily by its legal division. These regulations were supplemented by the Regulations on the Procedures for Handling Administrative Cases by Public Security Organs [Gong'an jiguan banli xinzheng anjian chengxu guiding] 2004 (amended in 2006 and 2012), which introduced several changes in the laojiao approval procedure. ${ }^{4}$. These regulations did not effectively address the abuses to which the system was prone.

The amorphous and unconstrained scope of laojiao was a problem from the perspective of rule of law principles of transparency, accountability, and predictability. The lack of procedural rules governing the decision to impose a period of laojiao also offended these principles. Laojiao came to be widely identified, even by the police themselves, as one of the most abused areas of police power (Li 1999). Discussion of abuse, illegality, and the need for either reform or abolition of laojiao was the subject of extensive domestic and international literature and advocacy (Amnesty International 2006; Chen and Zeng 2009; Chen, R. 2003; Chen, X. 2001a, 2001b; Chen and Cui 2008; Chen et al. 2002; Chu, Chen, and Zhang 2002; Clarke and Feinerman 1995; Congressional Executive Committee on China 2013; Dong 2002; Dui Hua 2010; Fan 2009; Feng, Liu, and Dai 2008; Hu 2003; Hu et al. 2007; Human Rights in China 2001; Hung 2002, 2003; Liu 1998, 2001; Mou 2013; Ren 1992; Wang 1997; Xia 2001; Yang 2008; Zhang, C. 2009; Zhang, M. 2008; Zhou 1999).

The process that led to the abolition of laojiao bears a close resemblance to the abolition processes of both shourong qiansong and shourong shencha, but the debate lasted for much longer and was much more public. After many years of debate over the legality and desirability of reforming laojiao, finally, in 2012 laojiao had its own public scandal. Rosenzweig (2014) documents spectacular injustice in the case of Tang Hui. A persistent petitioner, she was sentenced to eighteen months of laojiao for disrupting public order. Her petitioning sought the punishment she believed appropriate for the men responsible for abducting and forcing the prostitution of her eleven-year-old daughter. Even though Tang was released quickly, the public furor over her detention ended up being the final straw for laojiao.. 5 . This

\footnotetext{
4 See also the Regulations on Public Security Organs Handling Re-Education through Labor Cases
}

[Gong'an jiguan banli laodong jiaoyang anjian guiding] 2002 (amended in 2005), which provided for procedural rules specifically related to laojiao. See also the discussion in Biddulph (2007a).

${ }^{5}$ As the mother of an underage rape victim, Tang protested outside local government buildings, claiming that police had falsified evidence to mitigate the punishment of the men who had kidnapped and raped her daughter and forced her into prostitution. In August 2012, the police sentenced Tang to eighteen 
case coincided with resolve at the top political levels to abandon proposals to reform laojiao and to abolish it instead.

In January 2013, the CCP Central Political-Legal Committee identified the reform of laojiao as one of the four priority areas for reform that year (Cui and Liu 2013; Huang 2013). The minister of public security and secretary of the Political-Legal Committee, Meng Jianzhu, was quoted in January 2013 as advising that laojiao be phased out by the end of 2013 (CNTV 2013). In 2013, if not earlier, local police organs stopped sending people to laojiao. Coupled with the transfer of drug-dependent people from laojiao to coercive quarantine for drug rehabilitation beginning in 2008 , the number of people released from laojiao camps at the end of 2013 shrank dramatically. On December 28, 2013, the NPC Standing Committee issued the Decision on Repealing Legislation on Re-Education through Labor, which abolished laojiao.

Ultimately, before its abolition, laojiao had already been largely transformed into an administrative power to detain drug-dependent people (Biddulph 2015, 2016; Fu 2009).. For the declining number of people who remained punishable by laojiao after the transfer of drug-dependent people to coercive

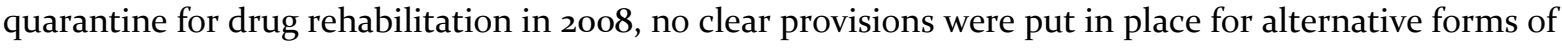
punishment. Reforms to address punishment of these groups have been made piecemeal and have included lowering the threshold of certain crimes so as to force a proportion of the more serious offenders into the criminal justice system. An institutional consequence has been the transfer of both the burden and the cost of punishing these minor offenders to the criminal justice system and to the local governments and justice agencies that have responsibility for implementing the system of community corrections (Biddulph 2016). This transfer of responsibility and administrative burden is surely problematic. As Li (2016) has argued, the community corrections [shequ jiaozheng] system lacks social support and financial resources, and, crucially, it is institutionally inconsistent with China's hukou [household registration] system.

Qiangzhi jiedu, qiangzhi geli jiedu [Coercive Drug Rehabilitation, Coercive Quarantine for Drug Rehabilitation]

While voluntary drug treatment had been an option for drug users since the 1950s, a system of compulsory drug detoxification existed in parallel. As official attention was refocused on the problems of drug use and addiction after the end of the Cultural Revolution, compulsory forms of drug detoxification were expanded throughout the country. The regulatory basis of compulsory drug detention was consolidated in 1990 when the NPC Standing Committee issued the Decision on Prohibiting Drugs [Guanyu jindu de jueding]. This regulation authorized the mandatory registration of drug users at public security bureaus, administrative detention on public security charges, compulsory drug rehabilitation [qiangzhi jiedu], and drug rehabilitation in laojiao for those who relapsed after compulsory detoxification (Article 8). Compulsory drug rehabilitation in detention centers operated by the police could last between three and six months and could be extended to a year if the police deemed it necessary (State Council Measures on Compulsory Drug Rehabilitation [Qiangzhi jiedu banfa 1995]. Drug-dependent people who relapsed after release from compulsory drug rehabilitation could be given a term of compulsory rehabilitation through labor at a laojiao facility lasting from one to three years, with a possible one-year extension (Measures on Compulsory Drug Rehabilitation 1995, Article 8) (Biddulph 2007a). The 1990 NPC Standing Committee Decision on Prohibiting Drugs led to profound changes in both the structure of the laojiao system and the regulatory and legislative framework on drug use.

months' detention at a laojiao facility in Yongzhou, Hunan Province, for "seriously disturbing social order and exerting a negative impact on society.” A public outcry helped secure her speedy release. In April 2013, the Yongzhou court rejected Tang's claim for compensation, but in July she won her case on appeal and was compensated RMB 2,941. 
Drug users had needs that were different from and more complex than those of minor offenders, sex workers, and their clients. Although in theory police-run drug rehabilitation facilities housed only drugdependent people, in some laojiao facilities they were held alongside other detainees, and in others specialist drug rehabilitation units were established. Overcrowded and underregulated, by the late 20oos, police-operated drug rehabilitation facilities outnumbered laojiao camps (Sapio 2010). As inmates in police-run drug detoxification centers who relapsed were sent to laojiao, laojiao institutions became filled with this new category of detainees and needed to adapt quickly to provide appropriate drug treatment. In 2004 the Ministry of Justice (MoJ) ordered the establishment of drug rehabilitation quarters within laojiao facilities (Ministry of Justice Standards on Modern and Civilized Re-education through Labor Camps [Xiandaihua wenming laojiaosuo biaozhun] 2004, Article 10). These quarters were gradually expanded into drug rehabilitation brigades and squads.

The haste with which rehabilitation facilities were set up meant that many of them were fairly small in scale and sometimes incapable of providing adequate treatment, because of a lack of sufficient funding or qualified personnel. The conditions in many centers endangered the health and safety of detainees (Biddulph 2007a). Between 1990 and 2007, nearly 3 million drug users transited through the compulsory rehabilitation system, and, as Chinese experts admitted, well over 85 percent of them relapsed into addiction after their release (Liu 2005). By the late 2000s, the majority of laojiao detainees were habitual drug users (Fu 2009). This simple fact, coupled with a rise among the laojiao population of drug userelated illnesses, such as hepatitis and HIV infection, placed an insurmountable strain on the laojiao system and on laojiao camps, which were poorly equipped to provide drug treatment and the necessary medical care. What made the governance of drug addiction even more problematic, however, was the realization in the mid-2ooos that the 3 million drug users who underwent compulsory treatment constituted only a small minority of the actual number of drug users, a number that remains unknown (Qi 2008).

As the domestic and international debate on the abolition of laojiao continued, an unexpected, though not unforeseeable, solution to the problems of the detention of drug-dependent people in laojiao came from the NPC. In 2008, it promulgated the Drug Prohibition Law [Jindu fa]; implementing regulations were issued by the State Council, with enactment in 2011 through the Drug Prohibition Regulations [Jindu tiaoli]. This law expanded the use of noncustodial coercive orders in the form of communitybased drug treatment orders as well as retaining the capacity to detain drug-dependent people for an extended period.

The Drug Prohibition Law and the Drug Prohibition Regulations rationalized the system of compulsory drug rehabilitation and replaced it with custodial and noncustodial measures. These measures were articulated on three levels for recreational users, occasional users, and habitual users. The new regulatory regime retained the system of the compulsory registration of drug users in a database compiled and maintained by the police. Habitual users, if they tested positive, could choose to undergo voluntary rehabilitation [ziyuan jiedu] (Drug Prohibition Law, Article 36; Drug Treatment Regulations, Article 11) - a measure that is voluntary and noncustodial—or, alternatively, be ordered to undergo rehabilitation in the community for three years (Drug Prohibition Law, Article 33). Habitual drug users who refused or were ineligible for voluntary rehabilitation became the targets of a new power, compulsory quarantine for drug rehabilitation [qiangzhi geli jiedu, CQDR], for an initial period of two years, which could be shortened or lengthened by one year (Biddulph and Xie 2011; Drug Prohibition Law, Articles 27, 38, and 43). The power to approve the imposition of a community-based coercive order or detention under CQDR is exercised by the police, which can also order addicts to undertake a period of follow-up treatment in the community [shequ kangfu] for a maximum of three years (Drug Prohibition Law, Article 48). Those who relapse can receive a further term of compulsory drug rehabilitation (Drug Prohibition Law, Article 38).

In 2008, on the eve of the promulgation of the Drug Prohibition Law, the existing police-operated drug treatment facilities were ordered to close. In locations with specialist drug rehabilitation facilities within existing laojiao facilities, the transfer of drug-dependent people to CQDR was effected by changing the nameplate at the front gate (Biddulph and Xie 2011). In other cases, laojiao facilities were expanded prior to being renamed in order to receive those who had until then been held at drug treatment facilities (Sapio 2010). 
This is the accepted version of the article published in:

(2017) 2(1) China Law and Society, 1-62

\section{Reforming the Remaining Administrative Detention Powers?}

The abolition of laojiao in 2013 by no means finally resolved the problems with administrative detention powers. Of the remaining administrative powers, some have a stable legal basis and are unlikely to be substantively reformed or abolished soon. Neither administrative detention under the Public Security Administrative Punishments Law nor the detention of drug-dependent people under the Drug Prohibition Law 2008 (discussed above) can be subject to claims that they lack a proper legal basis according to the Legislation Law. In some respects, these detention powers reflect a new or recently renewed political resolve to establish or maintain these existing forms of administrative detention. However, at least two remaining administrative detention powers-shourong jiaoyu (for detention of sex workers and their clients) and shourong jiaoyang (for detention of juvenile offenders)-are now subject to the same types of criticisms that preceded the abolition of shourong shencha, shourong qiansong, and laojiao.

\section{Shourong jiaoyu [Detention for Education]}

In the 198 os and the 1990s, the sex trade grew steadily, as did the increasing problems associated with drug dependency (Gao 2011; Jeffreys 2004). Policing of the sex trade was undertaken with measures substantively and procedurally similar to those introduced four decades earlier, in the 1950s. In certain localities throughout China, specialized detention centers for sex workers and their clients were established from 1984 (Biddulph 2007a, 2007b).. After a series of rather ineffectual attempts at bringing the sex trade under control, in 1991 the NPC Standing Committee's Decision on Strictly Prohibiting Prostitution and Using Prostitutes [Guanyu yanjin maiyin piaochang de jueding] consolidated all previous regulatory documents and mandated the use of shourong jiaoyu [detention for education] and laojiao for recidivist prostitutes and their clients (Biddulph 2007a, 2007b; Jeffreys 2004).

Sex workers and their clients may be subject to a range of administrative punishments imposed by the police. The 2006 Public Security Administrative Punishments Law [PSAPL; Zhi'an guanli chufa fa], as amended in 2012, authorizes the police to impose an administrative fine or administrative detention. The 1991 NPC Standing Committee Decision on Strictly Prohibiting Prostitution and Using Prostitutes [Guanyu yanjin maiyin piaochang de jueding] authorizes police to impose a period of shourong jiaoyu [detention for education] for between six months and two years. Before laojiao was abolished in December 2013, someone who had already been sanctioned for engaging in sex work or for paying for their services could have been subjected to a period of detention under laojiao. In a limited range of circumstances, a criminal punishment may be imposed under the Criminal Law for committing several prostitution-related offenses.

In practice, police prefer to impose a fine under the terms of the PSAPL because imposing detention is costly in terms of time and police resources. Relying on police fines is a more convenient enforcement option, but it merely imposes a financial burden on the sex worker that might be difficult to bear without the income earned through engaging in further sex work (on police enforcement practices see Boittin 2013).

As a practical matter, the rate at which people involved in the sex trade are detained under either detention for investigation or administrative detention is strongly influenced by a range of factors that are extraneous to the actual offenses. The rate at which detention is imposed increases when the police are instructed to carry out targeted campaigns against sex work and depends on the local availability of detention facilities. Administrative detention was not designed to provide sex workers with any real education, medical care, or vocational rehabilitation-nor does detention in shourong jiaoyu, despite propaganda to the contrary.

Shourong jiaoyu suffers all the same legal and practical problems as laojiao: disproportionately harsh sentences, the lack of a proper legal basis, uncontrolled discretion vested in the police to impose detention and to determine its duration, and little or no oversight or control. Recently, shourong jiaoyu has been implicated in two major scandals. The first involved a famous actor Huang Haibo, who, according to reports, was caught in flagrante with a sex worker named Liu Xinyu on May 15, 2014. Initially, a fifteen-day period of administrative detention was imposed upon both of them. Upon its 
expiry, both Huang and Liu were given a six-month period of shourong jiaoyu. Huang was subsequently released, but Liu was then prosecuted and convicted of the further offense of enticing a person into prostitution under Criminal Law Article 359 (Wang 2015; Zhang and Liu 2014)..6.

A much bigger scandal, even though less directly related to shourong jiaoyu, was the death of Lei Yang on May 7, 2016, as he was being taken into police custody. The circumstances of Lei's death remain unclear, but it is known that Lei was seized as part of a vice raid that police were conducting at the foot massage parlor that Lei was allegedly patronizing. ${ }^{7}$. His death focused attention and popular anxiety not only on policing practices generally but also on the policing of vice in particular. Now both police and the citizens they are charged with protecting wonder whether this approach to policing vice is either desirable or warranted and whether the detention of sex workers and their clients under this power should be abolished.

Shourong jiaoyang [Detention for Re-Education)

Detention for re-education is imposed on minors who have committed infractions that are not sufficiently serious to warrant a criminal sanction. Regulations governing detention for education are sparse and fragmented. A 1982 document issued by the MPS states that the period of detention should generally be between one and three years. It further states that approval for detention must be obtained from the county-level public security bureau. ${ }^{8}$. A range of different types of facilities serve as detention for education centers, work-study schools [gongdu xuexiao], or juvenile correctional facilities, but, in the case of juvenile correctional facilities, they must in theory be separated from facilities that incarcerate criminal offenders (Chen, $\mathrm{Z}$ 2004). In 1996 the MoJ issued a document instructing that all juveniles held in detention for education be transferred from juvenile correctional facilities to juvenile education camps [xiaonian laojiaosuo] managed by the Laojiao Bureau of the Ministry of Justice. ${ }^{9}$. Yet this form of detention lacks a proper legal basis and judicial oversight and involves extended periods of the deprivation of liberty. It is particularly problematic when the juvenile offender's conduct is seen as insufficiently serious to warrant a criminal sanction.

When juveniles engage in serious misconduct [yanzhong buliang xingwei], their parents or guardian are required to coordinate with their school to strengthen supervision or, where necessary, send them to a work-study school for rehabilitation (Law on the Prevention of Juvenile Delinquency 1999, Article 35). Serious misconduct is defined in the Law on the Prevention of Juvenile Delinquency (Article 34), including breaches of public order that are serious but insufficient to warrant a criminal sanction, such as gathering a gang to cause trouble, being repeatedly found in possession of prohibited knives, repeated gambling, repeatedly beating and abusing people, selling or distributing pornographic materials, promiscuity, prostitution, and smoking or injecting illicit drugs.

Shuanggui [Double Designation]

Shuanggui is an investigative detention measure used by Party discipline organs on members of the CCP suspected of criminal offenses, corruption, or misconduct. Despite having a variety of historical

\footnotetext{
${ }^{6}$ It is unclear precisely why Liu was charged with this offence based on the disclosed facts, or what conduct would have constituted such an offence in this situation.

7 The inference was that the foot massage parlour was a front for a brothel.

${ }^{8}$ Ministry of Public Security Notice on the Scope of Juvenile Offenders to Be Taken in and Detained in

Juvenile Correctional Facilities [Gong'an bu guanyu shaonianfan guanjiaosuo shouya, shourong fanwei de tongzhi], which took effect May 1, 1982.

${ }^{9}$ Ministry of Justice Measures for Management of the Work of Education of Juveniles (for trial implementation) [Shaonian jiaoyang gongzuo guanli banfa (shixing)], January 22, 1996, and the Notice
} on Transferring Juvenile Offenders Undergoing Detention for Education to laojiao to Undergo Detention for Education. 
precedents that date back to the imperial era (Sapio 2008), shuanggui was reintroduced in late 1989 in an entirely informal way, following an oral directive issued at the height of the 1988 anti-corruption campaign. Throughout the 1990s, the CCP Central Committee and the Central Commission for Discipline Inspection began making broader and more systematic use of their regulatory powers over the conduct of CCP members. One result was an increasingly complex and precise definition of the substantive and procedural content of Party discipline, which led to the birth of an immense corpus of Party legislation. Nowadays, shuanggui is part and parcel of this body of regulatory documents as well as of state legislation.

In 1990, the Ministry of Supervision, an anti-corruption organ with jurisdiction over state officials but not Party members, introduced the power to investigate civil servants suspected of corruption and to serve them with summons. This power was initially based on the 1990 Regulations on Administrative Supervision [Xingzheng jiancha tiaoli] and subsequently on the 1997 Administrative Supervision Law [Xingzheng jiancha fa]. The capacity to "order concerned parties to appear at a specific time and place to provide an explanation of the matters under investigation" ". became known colloquially as "the two specifics" [lianggui], a shorthand reference to the time and place of questioning. The thin line separating public officials and Party members, however, led to most state officials being detained for Party disciplinary offences. This circumstance made it necessary for Party discipline organs to endow themselves with the same powers enjoyed by their state counterparts: the administrative supervision authority. They did so in 1994 by enacting the Regulations on the Work of Case Investigation by Discipline Inspection Organs [Zhongguo gongchandang jilü jiancha jiguan anjian jiancha gongzuo tiaoli], in which Article 28 largely repeats the wording of the Regulations on Administrative Supervision, stating that Party discipline organs could "require the concerned personnel to appear at a designated time and place to provide an explanation of problems pertaining to their case.". ${ }^{11}$

Shuanggui thus became perhaps the most important power of the Party discipline organ. This measure underwent a slow and constant process of development, driven largely by the need to reduce the number of suicides, as well as deaths under torture, that could take place at the hands of untrained, vengeful, and unconstrained Party discipline officials. Most of the regulatory documents on shuanggui were classified as being only for internal circulation [neibu wenjian] until very recently. As the institutionalization and regularization of shuanggui proceeded, all regulatory documents enacted from the 1990 until 2012 have been released to the public. The only exception is the 2012 Central Commission for Discipline Inspection Rules on Using the Measure of Lianggui. To date, this document has not been published; however, available accounts describe how this is gradually bringing shuanggui more into line with the detention powers wielded by state organs.

\section{Xingzheng juliu [Administrative Detention]}

Punishment for minor administrative infractions gained legislative basis with the Public Security Administrative Punishments Regulations [Zhi'an guanli chufa tiaoli] originally passed in 1957. The Regulations authorized sending vagrants or the unemployed, after an initial sanction under these regulations, to laojiao. The regulations were passed again almost thirty years later in 1986 and were upgraded to the status of law in 2006 to reflect changes in the legal system, particularly those strengthening mandatory procedural rules for the imposition of a punishment and was further amended in 2012. Further amendments to the law are proposed, with a discussion draft released in 2017.

${ }^{10}$ People's Republic of China Regulations on Administrative Supervision, Article 21(5), issued December 9, 1990, and took effect on the same date. The Regulations were repealed on May 9, 1997, and have been replaced by the Administrative Supervision Law. Shuanggui is currently based on the Administrative Supervision Law, Article 20(3), issued May 9, 1997, and took effect on that date.

${ }^{11}$ Chinese Communist Party Regulations on the Work of Case Investigation by Discipline Inspection Organs), Article 28(3), issued March 25, 1994, and took effect May 1, 1994. 
The Public Security Administrative Punishments Law [Zhi'an guanli chufa fa] is the primary legislative basis for imposing administrative punishments for minor offenses. It enables police to give someone whom they deem a minor offender a warning, an administrative fine, or a maximum twenty-day period of administrative detention [xingzheng juliu] in a detention center within the police station [paichusuo]. But despite the extensive use of this law to impose a period of administrative detention, both the law and the practice have drawn little academic scrutiny (Biddulph 2008b).

\section{Liuzhi panwen [Detention for Interrogation]}

An example of an administrative detention power that is commonly used by police to detain and interrogate suspects to enable the opening of a criminal investigation is liuzhi panwen. The 1995 People's Police Law, Article 9 (as amended 2012), states that the police may conduct an on-site interrogation of people who are suspected of committing an administrative violation or a crime. The police may then take someone to the police station for further interrogation, for an initial period of twenty-four hours and no more than forty-eight hours, in a wide range of circumstances: for being accused of a criminal offense, for being suspected of committing an offense at the scene, if they cannot produce identity documents or refuse to reveal their identity and for being suspected of committing an offense or of carrying articles that were probably obtained illegally (Article 9). A person so detained may be subjected to another compulsory measure, whether administrative or criminal, when evidence is found to support further action.

\section{Comparing Administrative Detention Powers to Criminal Detention Powers}

Over the past two decades, the scope of criminal detention powers has been influenced by resource constraints, such as lack of prison space, but more often by policies seeking to reduce the use of detention in both criminal punishments and criminal coercive measures. In the area of criminal punishments, community corrections has played an important role in expanding the use of noncustodial punishment for minor offenses. In the area of criminal coercive powers, despite the continuing strong overall preference of the police for using criminal detention and arrest when investigating suspected criminal offenses, they have been willing to expand the use of qubao houshen [generally equated to bail] in cases involving juveniles and minor offenses when the accused has a local household registration.

Although administrative and criminal forms of detention have not necessarily evolved in a consciously coordinated manner, criminal justice system detention has expanded as a consequence of reform in the realm of administrative detention. One consequence of the abolition and reform of some of the administrative detention powers discussed above has been to put a greater burden of detention on the criminal justice system. For example, the abolition of shourong shencha was achieved by expanding criminal detention and arrest powers. The abolition of Re-education through Labor was accompanied by a lowering of the threshold for certain crimes in both the eighth and ninth amendments to the Criminal Law (2011 and 2015 respectively) to capture some of the conduct originally punished under the administrative system of Re-education through Labor.

In the section above, we outlined a range of elements that were present in the reform of administrative detention powers. These considerations are that popular and international criticism has created a politically advantageous platform for reform in the criminal justice system; that reform can be achieved without harming public order; and that alternatives are available if a decision has not been made to exempt that conduct from regulation and punishment. Similarities to the reform of administrative detention powers include egregious abuse and sustained criticism of those abuses. Several major scandals involving criminal detention, for example, the "Hide and Seek" case discussed below, have focused public and official ire, which precipitated an institutional response.

However, administrative powers have some distinctive features that are not shared by detention in the criminal justice system. Many administrative forms of detention entirely lack a legal basis. Thus as the legal system has become more comprehensive in recent decades, a merging of criticisms based on illegality with broader debates about the efficacy and the desirability of retaining or reforming these administrative powers has become inevitable. The same cannot be said for criminal detention powers, which have a legal basis in the Criminal Law or the Criminal Procedure Law. Efficacy, desirability, and 
legitimacy cannot be challenged by critics in terms of their legality but must be framed in terms of the ability of these powers to deliver justice. The current post-2013 round of judicial reforms has determined that changes to the criminal justice system are to be incremental, thus excluding radical reorganization of criminal coercive and punitive powers. To date, no persuasive supra-legislative norms exist that can effectively be brought to bear in promoting deeper reform. The rhetoric of people-oriented governance and the constitutional protection of human rights both lack sufficiently specific norms to provide strong support for human rights-oriented reforms. International human rights norms, too, are embraced to the extent and in the ways that suit the Party-state. Institutionalized in law, the criminal justice system is comparatively more rigid and thus less amenable to the scale of change that has occurred in some areas of administrative detention.

An example is pre-arrest detention, discussed in more detail below. Nesossi (2012) documents that, in both the drafting process and the years that followed enactment of the 1996 amendments to the Criminal Procedure Law, the issue of pretrial detention became a much greater concern for legal scholars, lawyers, and members of the procuratorate. Some began to question a broader range of issues relating to criminal detention: the pervasiveness of pretrial detention, the strict linking of arrest with detention, abuses in the residential surveillance system, and the monopoly of the public security authorities over the exercise of these powers. Chen Weidong, a professor of criminal procedure at Renmin University, was one of the most vocal in claiming that several of the measures used to deprive citizens of their personal liberty in both the administrative and criminal justice systems constituted serious violations of individual rights and freedom (Chen 2004; Chen W. 2005; Sun 2007). However, the reform enacted in 1996 balanced the abolition of the administrative power of shourong shencha with expansion of the time limits for pre-arrest detention and expansion of the scope of arrest. The result was that police powers were reorganized, rather than restricted.

Even after the passage of the 1996 Criminal Procedure Law, the international community continued to seek to shape debates over the reform of deprivation of liberty in terms of international human rights norms. In the mid-2ooos, international civil society groups started to implement projects seeking to improve detainees' conditions of detention and enhance the supervision of pretrial detention centers and prisons (Macbean 2016; Nesossi 2012, 2014). Visits to China by two United Nations bodies-the Working Group on Arbitrary Detention in December 2004 and the Special Rapporteur on Torture and Other Cruel, Inhuman, or Degrading Treatment or Punishment a year later-reported that the rules of criminal procedure and practice concerning pretrial detention in the PRC did not conform to international laws on human rights. They recommended restricting the pretrial detention period and extending noncustodial measures, especially for nonviolent, minor, or less serious crimes (United Nations 2006; UN Working Group on Arbitrary Detention 2004). In this instance, as seen below, international pressure has been insufficient to achieve reform of pre-arrest detention.

\section{Reforming Criminal Detention and Deprivation of Liberty Powers}

In contrast to administrative detention powers, most criminal detention powers have enjoyed a more stable legal basis. In fact, since 1980 all existing criminal detention powers, with the exception of detention in a psychiatric hospital, have been based on the Criminal Law and their application (at least in formal legal terms) has been dictated by the Criminal Procedure Law.

Generally speaking, the reform of criminal detention powers has proceeded at a much slower pace than reform of administrative detention powers. However, in recent years, the scope of some detention powers has expanded to include conduct previously dealt with under the exclusive jurisdiction of administrative organs or Party discipline organs. A case in point is the use of residential surveillance, and residential surveillance at a designated location, following the 2012 reform of the Criminal Procedure Law. Below we outline criminal detention and deprivation of liberty powers, their nature, legal basis, and evolution over time.

\section{Xingshi juliu [Pre-Arrest Detention]}

Pre-arrest detention [xingshi juliu] is a police power based on the 2012 Criminal Procedure Law (Article 80). This power can be used for seven different categories of targets: (1) those who are discovered committing a crime, making preparations to commit a crime, or immediately after committing a crime; 
(2) those who have been identified as perpetrators of a crime by a witness or a victim; (3) those who are found to possess evidence of a crime; (4) those who attempt to commit suicide or to flee after committing a crime; (5) those who destroy or fabricate evidence or provide statements indicating collusion with others; (6) those who decline to state their real name or address; and (7) suspects in major transprovincial crimes or gang members. The period of pre-arrest detention can last up thirtyseven days. Article 89 of the 2012 Criminal Procedure Law states two different time limits during which the public security organs can apply for an arrest warrant after having taken a suspect into custody. First, in general circumstances, the public security organs have three days to file an arrest request with the people's procuratorate for examination and approval. Under special circumstances, the time limit for filing such a request can be extended for one to four days. The 2012 Criminal Procedure Law does not define "special circumstances." Second, when the public security organs suspect that a person might have committed transprovincial crimes, or multiple crimes, or be involved in a criminal gang, the time limit for filing a request for examination and approval of arrest may be extended to thirty days. In practice, public security organs prefer to use this second option to obtain a thirty-day extension (McConville et al. 2011; Rosenzweig et al. 2013). After a written request for approval of an arrest is received, the people's procuratorate has seven days to make a decision on whether to approve or reject the arrest.

The power to detain someone for thirty days was added in the 1996 revision of the 1979 Criminal Procedures Law to enable the detention of people who were previously subject to shourong shencha. ${ }^{12}$. According to Article 48 of the 1979 Criminal Procedure Law, the public security bureau could detain a person for only three days before making an application for arrest to the procuratorate, with a possible extension of up to four days, and the procuratorate had to respond within three days. Thus the total possible time for criminal detention under the 1997 law was ten days.

Arrest approval by the procuratorate has long been considered a mere formality. Macbean (2016) and McConville et al. (2011) note that some procuratorates even fail to distinguish between approval of an arrest and the decision to initiate a prosecution. To strengthen procuratorial oversight, in 2010 the SPP and MPS issued the Regulations on Issues Concerning the Supervision of Filing Criminal Cases [Guanyu xingshi li'an jiandu you guan wenti de guiding], which stipulates that the procuratorate question suspects before approving an arrest in circumstances involving juveniles, when the procuratorate has doubts about the way in which evidence was obtained, or when indications exist of a coerced confession. In an attempt to strengthen the role of the procuratorate in examining the necessity for arrest and detention, the 2012 Criminal Procedure Law (Article 86) sets out similar requirements. However, the shortage of personnel and the tight time limits set for approving an arrest continue to make the procuratorate's supervisory role over arrest procedures quite ineffective (Macbean 2016).

Provisions on pre-arrest detention work together with rules that enable searches and seizures to be conducted in the absence of a warrant (Articles 111 and 136 in the 1996 and 2012 Criminal Procedure Law, respectively). After the initial detention, the police have an obligation to inform the relatives of a criminal suspect or his/her work-unit. However, information about the place and date of detention can be omitted in cases in which such a communication would obstruct the investigation (Article 64, 1996 Criminal Procedure Law) or when "communication is not possible" [wufa tongzhi]. Suspects placed under initial detention must be questioned within twenty-four hours (Articles 65 and 83 in the 1996 and 2012 Criminal Procedure Law, respectively), yet the law does not set precise limits on the duration and quantity of the interrogations or the time of day when they can be held. The 2012 reform to the Criminal Procedure Law widened these loopholes, allowing public security organs to decline to notify family members about a detention in cases of crimes against state security and terrorism (Article 83). These circumstances allow public security organs in some cases to use initial detention to serve goals and priorities other than crime control and to target a broad range of groups-including, but not limited to, political dissidents - who are perceived to pose a threat to the political stability of the country.

During this potentially lengthy period, the person in custody formally enjoys a right to legal representation. However, defense lawyers often find themselves unable to access even the most basic

\footnotetext{
${ }^{12}$ See section above on "Reform of Administrative Detention Powers."
} 
information about their clients. First and foremost, no well-established, well-defined rule exists with respect to notification of pre-arrest detention. Article 83 of the 2012 Criminal Procedure Law and Article 123 of the 2012 MPS Regulations on the Procedures for Handling Criminal Cases [Gong'an jiguan bali xingshi anjian chengxu guiding] state that public security organs are required to inform the person's family within twenty-four hours. As mentioned above, however, this duty does not extend to those suspected of crimes against national security and terrorism. Notification is to be provided to family members, rather than to a defense lawyer. Moreover, notification does not include any information on whether or when the police intend to apply for an arrest warrant. The absence of a clear duty to provide this information gives public security organs substantial discretion over when they apply for an arrest warrant. Significant discretion is also enjoyed by the procuratorate, as defense lawyers have no way of ascertaining the precise stage of the pre-arrest proceedings. In fact, meetings between a defense lawyer and his/her client can take place only after the prosecutor formally issues an indictment. Until that stage, public security organs enjoy a substantial advantage over the defense, as they have a right to question the suspect multiple times in the absence of a legal counsel.

\section{Arrest and Detention Pending Trial}

Under the 2012 Criminal Procedure Law, arrest [daibu] refers to the action approved or taken by the procuratorate or decided by the court with respect to those suspected of having committed a criminal offense and where sufficient probative evidence exists. An arrest warrant may be obtained when suspects can be convicted of an imprisonable offense and the use of residential surveillance would not be sufficient to prevent them from carrying out acts including: committing a new crime, posing a danger to national security, public security, or social order, destroying or forging evidence, interfering with the testimony of a witness or colluding with others to make a false confession, retaliating against a victim, informant, or accuser, or attempting to commit suicide or escape (Article 79).

The legislation does not make a clear distinction between arrest and detention pending trial, and detention is the inevitable result of an arrest. Moreover, arrest and detention usually continue until the end of a suspect's trial and sentencing (Dan 2012). Pursuant to Articles 154, 156, and 157 of the 2012 Criminal Procedure Law, a criminal suspect may be held in custody during the investigation period for up to seven months following arrest. However, Article 158 specifies two circumstances in which the police may recalculate the starting date of the period of investigation: first, if the police discover that the suspect may have committed a crime other than the one under investigation; and, second, if the suspect refuses to reveal his/her identity (name and address), the clock only starts after the identity has been verified.

At the end of the investigation period, the case is transferred from the public security organs to the procuratorate, whose duty is to decide whether to initiate a prosecution. According to Article 169 of the 2012 Criminal Procedure Law, the procuratorate has one month to make a decision, although an extension of half a month may be allowed in major and complex cases. Moreover, according to Article 171, if the procuratorate deems it necessary, it may remand the case to the police for supplementary investigation [buchong zhencha]. Two supplementary investigations (of no more than thirty days each) may be requested by the procuratorate. Articles 169, 171, and 172 together enable six and a half months to elapse between the end of the investigation and the issuance of an indictment, taking into account the time for supplementary investigations. Only after the procuratorate determines that the facts of the crime have been ascertained, that the evidence is reliable and sufficient, and that criminal responsibility should be investigated will it initiate a public prosecution in the people's court.

Throughout the process, the criminal suspect generally remains in detention. In the PRC, there is no right to bail [qubao houshen, literally "taking a guarantee and awaiting trial"]. The 2012 Criminal Procedure Law defines the circumstances in which bail can be granted (Article 65); it also states that, to obtain bail, a criminal suspect or defendant must provide a guarantor or pay a bond (Article 67). However, strong disincentives remain to becoming a guarantor; not only are guarantors required to post bail but they must also supervise and report infractions of any of the conditions under which pretrial release is approved. Guarantors deemed to have failed to comply with these obligations face fines or even criminal prosecution (Articles 68-70). 
This is the accepted version of the article published in:

(2017) 2(1) China Law and Society, 1-62

Jianshi juzhu [Residential Surveillance]

Residential surveillance [jianshi juzhu] was originally intended to be a noncustodial alternative to arrest, to be used in relatively limited circumstances. It was one of various coercive measures justified on the grounds that they ensure the smooth running of criminal proceedings "to prevent suspects from interfering with an investigation or continuing in criminal activities" (Song 2007, 11).

The 1979 Criminal Procedure Law stated that law enforcement and judicial agents were authorized to use residential surveillance under one of the following five conditions: (1) when an offense was relatively minor and did not warrant punishment by imprisonment or death and there is no need for arrest; (2) when the main facts of the case had been ascertained and punishment by imprisonment was indicated but noncustodial measures were sufficient to prevent further harm to society; (3) when arrest was necessary but the individual suffered from an acute, highly infectious, or otherwise serious illness; (4) when arrest was necessary but the suspect was a woman who was either pregnant or nursing an infant; or (5) when arrest is indicated following the use of criminal detention but there was insufficient evidence to obtain approval from the procuratorate (1979 Criminal Procedure Law, Articles 38, 40, and $44)$.

According to Article 38(2) of the 1979 Criminal Procedure Law, residential surveillance meant prohibiting a suspect or defendant from leaving a "designated area" [zhiding quyu]. The measure was to be enforced by the local public security organ; however, this responsibility could also be delegated to the people's commune or work-unit to which the individual was connected.

As Rosenzweig (2016) notes, the vague definition of residential surveillance in terms of its targets and enforcement made it open to abuse during the 1980 os and 1990s. These abuses included police using residential surveillance for persons on whom no coercive measures should have been used (e.g., witnesses or other persons with knowledge of the case) or factories and enterprises adopting it to deal with disciplinary matters that did not rise to the level of a criminal offense. At times, improper use of residential surveillance also entailed using it where custodial detention or arrest was called for. Problems also arose from the lack of statutory specificity regarding the meaning of the "designated area" in which residential surveillance was to be enforced. This meant that this area could be a room in a guesthouse, a space inside the local police station or work-unit, or even a detention center. These problems led critics to worry that the measure could turn into an abusive form of complete isolation and deprivation of personal liberty.

In addition, Rosenzweig (2016) notes that residential surveillance was also particularly problematic as the 1979 Criminal Procedure Law was silent about any punishment for escape from residential surveillance. This created two incentives that discouraged the use of residential surveillance as a replacement for custodial detention. Investigators felt more certain about the ability of arrest and detention to ensure that suspects would be present for trial and could not pose any threat to society. In the rare occasions when residential surveillance was used, enforcement agencies had an incentive to place targets in isolation by employing stringent conditions, increasing the risk that residential surveillance would devolve into a form of "disguised detention" [bianxiang juliu]. Because of loopholes in the legislation, the police could also delegate enforcement responsibility to others (e.g., work-units) and could extend the time limit for residential surveillance to make it a form of "life imprisonment." The discussions leading to the amendment of the 1979 Criminal Procedure Law in 1996 highlighted these problems and led many in the Chinese legal community to advocate for the court's abolition of residential surveillance. However, the measure was ultimately retained and new provisions were added to the 1996 Criminal Procedure Law to define: the circumstances under which residential surveillance could be applied (Article 51), rules governing its implementation, including new limits on the suspect's ability to meet with other people during the period of residential surveillance (Article 57); and time limits concerning the duration of its enforcement (Article 58). The revised law also obliged a person placed under residential surveillance to remain within his or her "domicile" [zhuchu] unless given permission to leave and stated that "those without a fixed domicile" could be confined to a "designated residence" [zhiding de jusuo] (Article 57). In addition, it established a shorter time limit for residential surveillance (six months) following release on guarantee pending trial (an approximation of bail) (one year) (Article 58). 
In 1998 the MPS issued the Procedural Regulations for the Handling of Criminal Cases by Public Security Organs [Gong'an jiguan banli xingshi anjian chengxu guiding], which included provisions explaining that residence qualified as "fixed" if it was (1) "legal" [hefa] and (2) located in the jurisdiction of the public security organ investigating the case (1998 MPS Procedural Regulations, Article 98).. The MPS regulations also placed limits, in principle, on the locations available for use as "designated residences," explicitly prohibiting public security organs from establishing dedicated facilities or using detention centers or public security "work locations" for the purpose of implementing residential surveillance (Article 98).

Notwithstanding the statutory limits imposed on residential surveillance in the criminal legislation, residential surveillance continued to be a widely abused measure used to secretly detain criminal suspects and make them disappear. Originally intended as a fairly lenient and noncoercive alternative to pretrial detention, similar to house arrest in Western countries, it developed over time into a distinctive and highly coercive measure. Thus in the lead-up to the revision of the Criminal Procedure Law in 2012, this was one of the areas in which public opinion was particularly active. Both foreign and domestic scholars registered their apprehension about the nature and scope of these developments, using the public consultation process during the final drafting stage of the 2012 Criminal Procedure Law reforms as a propitious time to express their concerns and advocate for the abolition of this measure (Rosenzweig 2016).

Residential surveillance was ultimately retained in the 2012 amendments to the Criminal Procedure Law but in a substantially revised form (Cheng 2016; Rosenzweig 2016). Today, it includes two quite distinct measures. The law justifies both an "ordinary" form of residential surveillance intended primarily as a tool for reducing pretrial detention and an "exceptional" nonresidential form used to deal with offenders whom authorities consider serious threats to the sociopolitical order. According to Article 73 of the 2012 Criminal Procedure Law, the authorities can designate a location for residential surveillance either when the suspect lacks a "fixed residence" or in the following circumstances: (1) the case involves offenses of endangering state security, terrorism, or "extremely serious bribery"; (2) enforcement of the residential form of residential surveillance has the potential to "impede the investigation"; and (3) permission is granted by a superior-level procuratorate or public security organ. However, neither the 2012 Criminal Procedure Law nor the related procedural Regulation issued by the MPS and SPP ${ }^{13}$. define the "legality" of a residence in the context of criminal procedure and only vaguely define the conditions for "designated residence." Its critics see in such vagueness the potential risk that residential surveillance will continue to offer opportunities for physical and psychological abuse.

\section{Juyi [Criminal Detention]}

Criminal detention is a punishment that should not be confused with pretrial detention, discussed above. Although pretrial detention is a form of investigative detention, criminal detention is one of the five principal punishments introduced by the Criminal Law in 1979. Criminal detention is to be used for no less than one month and no more than six months and is enforced by public security organs (1979 Criminal Procedure Law, Article 42). Formally, offenders held under criminal detention have the right to return to their homes for one or two days a month, although the implementation of the punishment can be suspended [huanxing] for between two months and one year (Article 73). Criminal detention is one of the lesser punishments, used mostly for offenders who have committed crimes deemed to have caused a low level of social harm. Despite this fact, the 1979 Criminal Procedure Law stipulated that people responsible for these lesser crimes be detained prior to trial at the same facilities as those used for those sentenced to fixed-term imprisonment or to life imprisonment (Article 156), allowing only extremely limited possibilities for prisoners to serve their sentence outside these facilities (Article 157).

${ }^{13}$ Ministry of Public Security Procedural Regulations for the Handling of Criminal Cases by Public

Security Organs [Gong'an jiguan banli xingshi anjian chengxu guiding]; Supreme People’s Procuratorate

(Provisional) Criminal Procedure Rules for People's Procuratorates [Renmin jianchayuan xingshi susong

guize (shixing)], which took effect January 1, 2013. 
The 1996 revision of the Criminal Procedure Law relaxed the regime of criminal detention, allowing release on bail or the use of residential surveillance for criminal suspects who could be punished with criminal detention (Article 51(1)). Moreover, these offenders could be tried using a simplified procedure (Article 154). The 2012 revision to the Criminal Procedure Law did not introduce significant reforms to this power. Academic research has not paid sustained attention to criminal detention, and no specific studies on this power exist in Western literature.

\section{Imprisonment}

Fixed-term imprisonment [youqi tuxing] and life imprisonment [wuqi tuxing] are criminal coercive measures based on the 1997 Criminal Law and the 2012 Criminal Procedure Law and apply to offenders who have been found guilty in a court trial. Currently, the length of imprisonment ranges from six months to fifteen years (1997 Criminal Law, Article 45). "Life imprisonment" is served for between fifteen and twenty years in prisons [jianyu], where inmates are required to perform forced labor and to receive ideological education (Article 46).

In contrast to other administrative and criminal detention measures, the law relating to short-term imprisonment, from six months to five years, has not been subject to significant reform. However, in recent years, legislators have sought to lengthen the time of imprisonment for those serving life sentences in two significant ways.

The first relates to China's two-year suspended death sentence [sihuan]. This death sentence is converted to a life sentence after a two-year probation period if the prisoner does not commit a further offense during that period. In past years, many judges were reluctant to impose the suspended death sentence because they argued that it was too easy for a prisoner whose sentence was commuted to a life sentence to further whittle down the sentence to around fifteen years through good behavior (Trevaskes 2013). In 2011, the NPC passed an amendment to Article 50(2) of the Criminal Law to restrict commutation of punishment in cases in which a judge determines that a capital crime is particularly malicious but "immediate execution of the offender is not necessary." This amendment allows a judge to impose a suspended death sentence and to place a "restriction on commutation" of the sentence in cases of particularly malicious murder, rape, robbery, kidnapping, arson, causing of explosions, spreading of hazardous substances, and leadership of a criminal organization. The result is that when a suspended death sentence is commuted to life imprisonment after two years, if the judge so decides, the actual time served cannot be less than twenty-five years (Liu 2012). For offenders given a sihuan sentence that is not subject to a restriction on commutation, the minimum amount of time served is fifteen years.

The second main reform relates to a new system of life sentences without parole. Progressively beginning in 2011, an increasing number of nonviolent crimes have been removed from the list of capital offenses, and nowadays the death penalty is used extremely sparingly in corruption cases. To make these reforms more palatable to a cynical public that is wary of "lenient sentencing" for Party and government officials, the Criminal Law was amended in 2015 to give the most serious corrupt officials a new sentence of "life without parole": this came with the introduction of a new "life without parole" system. Punishments for corruption are now divided into three levels depending on the quantity of funds embezzled: "larger," "huge," or "especially huge," with a suspended death sentence, rather than immediate execution now the norm for extremely serious bribery or embezzlement cases involving over RMB 3 million Xinhua 2016). For instance, in the past, officials sentenced to death with a two-year suspended sentence would have had their sentence commuted to a life sentence at the completion of a two-year probation period and then could receive further reductions for good behavior. The 2015 "life without parole" amendment now means that a court handing down a suspended death sentence can concurrently hold that the offender is never eligible for parole or further commutation.

\section{Liuchang jiuye [Retention for In-Camp Employment]}

Retention for in-camp employment dates to the 1950s. This measure was born in the context of reform through labor in the Chinese prison system. Then known as forced job placement, this measure was based on a document enacted in 1954, the Government Administrative Council Temporary Measures on Handling Criminals Who Have Served Their Term of Reform through Labor and Their Job Placement 
[Zhengfuyuan laodong gaizao fanzui xingman shifang ji anzhi jiuye zanxing chuli banfa]... ${ }^{14}$ It enabled prison inmates who had served their sentence to be further compelled to continue to work at prisonowned factories or farms even after their sentence was served. Retention for in-camp employment had two ostensible rationales: in an environment when former convicts had difficulty finding employment after release, it enabled former inmates to be employed after their release, and it gave authorities a way of maintaining control over those inmates who were deemed socially dangerous because they had made attempts to escape during their term of imprisonment or were recidivists. Rhetoric suggesting that remaining in a prison camp after the sentence had been served was voluntary is belied by the coercive nature of this form of 'job placement'.

At the beginning of the reform era in 1981, the use of liuchang jiuye was reaffirmed by the NPC Standing Committee. In the Decision on the handling of offenders undergoing reform through labour or reeducation through labour who escape or commit new crimes, the NPC Standing Committee specified the circumstances in which a person could be retained for in-camp employment. These included people who committed new offences within three years of being released from re-education through labour, or within five years of escape. These people were to have their term extended and then be retained incamp for employment, as well as having their resident permit to live in a large or medium sized city revoked. Similar provisions applied to criminal convicts, who would have their sentence extended if they escaped. If they reoffended, this would be considered an exacerbating factor in sentencing and after serving this additional term they were to have their urban household registration revoked and be retained in the prison camp. People originally with rural household registration were not similarly barred from returning home. In the early days of reform, before the expansion of an employment market, the practical impact of revocation of an urban residence registration was that these people could not return to their home or find work in a large or medium sized city after release. The legality of such a measure was never clearly established and, after the Prison Law was passed in 1994, this form of detention was phased out.

\section{Detention of Offenders Mentally Incompetent to Bear Criminal Liability}

Compulsory treatment [qiangzhi yiliao] and involuntary hospitalization [fei ziyuan zhuyuan zhiliao] have been practiced for decades in China. The power to detain those with a mental illness traversed both criminal and administrative systems of detention until 2012. The 2012 amendments to the Criminal Procedure Law resulted in the formalization of this power, through the addition of a special chapter on procedures for dealing with those who had committed a crime but were judged to lack sufficient mental competence to be held criminally liable. Procedures introduced in the Criminal Procedure Law were complemented by the Mental Health Law [Jingshen weisheng fa], which was enacted in 2012 after twenty-seven years of intense debate (Guo 2016). To date, the most comprehensive works on detention in psychiatric hospital are by Guo Zhiyuan (2016) and Robin Munro (2000, 2007). Their works examine two distinct stages in the development of regulations on detention in a psychiatric hospital: Munro has conducted extensive research on detention in psychiatric hospitals as an administrative system of detention, and Guo has focused on the post-2012 criminal regime.

The 2012 Criminal Procedure Law identifies two circumstances in which those with mental illness can be deprived of their liberty and treated against their will in a mental health facility. The first is when a mentally ill person commits a violent act that would constitute a crime if carried out by someone who is mentally stable. The second is when it is determined that an individual's personal safety or the safety of others may be compromised because of the individual's mental disorder (Guo 2016). Such patients can be hospitalized and medicated without their consent or the consent of their guardians.

The 2012 Criminal Procedure Law define procedures for the treatment of a mentally ill person who has committed a violent act but because of mental illness is exempt from criminal liability. It states that

${ }^{14}$ See Article 2 of Government Administrative Council Temporary Measures on Handling Criminals Who

Have Served Their Term of Reform through Labor and Their Job Arrangement, issued on August 26, 1954, and took effect on that date. 
when the violent behavior compromises public security or seriously endangers the personal safety of other citizens, the mentally ill person is subject to involuntary medical treatment as determined by the people's court (Articles 284, 285). Before a people's court makes a decision to impose involuntary medical treatment, the public security bureau may take interim protective restraint measures (Article 285). The people's procuratorate is responsible for overseeing the decisions to impose and to carry out involuntary medical treatment (Article 289). In theory, detention for the treatment of such persons in an MPS-run psychiatric facility is not considered punishment but a preventive measure aimed at avoiding the occurrence of another offense (Guo 2016).

\section{Places of Detention and Their Management}

In the criminal justice system, criminal suspects, defendants, and convicted criminals can be detained at police stations, pretrial detention centers (before or after arrest), and prisons. Reforms in the management of these detention sites is discussed below.

\section{Kanshousuo [Pretrial Detention Centers]}

Bail is still not commonly granted in China. The vast majority of criminal suspects arrested or charged with a criminal offense are remanded to pretrial detention centers, which are usually separate from police stations and prisons, and remain under the control of the organs of public security. In the early 1980s, the CCP Central Political-Legal Committee [Zhongyang zhengfawei] considered whether responsibility for both prisons and pretrial detention centers could be transferred to the MoJ, but the idea was quickly dismissed. With the first Strike Hard campaign (1983-86) then under way, the police rationalized the need to maintain their stronghold on at least one form of criminal detention without having to rely on the newly re-established MoJ (restored in 1979 after its dissolution during the Mao period) to facilitate coordination among investigation, arrest, and detention (Nesossi 2012).

However, recurring exposés of abuses of power and torture during interrogations have highlighted the need for institutional reform of pretrial detention. Calls to reform these centers relate precisely to the potentially conflicting double function that the public security organs serve: investigating individuals while also detaining them (Cheng 2014). This creates a situation ripe for abusive practices by public security officers against detainees because activities such as extracting a confession through torture [xingxun bigong] are more easily condoned or concealed in the guise of obtaining evidence.

In China today, the State Council's 1990 Regulations on Criminal Detention Centers [Kanshousuo tiaoli) and 1991 Methods for Implementing the Regulations on Criminal Detention Centers [Kanshousuo tiaoli de shishi banfa) continue to regulate the work of the police in pretrial detention centers as well as the conditions under which detention should be carried out (Cheng and Nesossi 2016; Nesossi 2012). The 1990 Regulations are supplemented by more than fifty rules, notices, and opinions - not counting local legislation-issued by the MPS (sometimes jointly with other ministries, the SPC, and the SPP) to regulate all the various aspects of pretrial detention. The 1990 Regulations have remained untouched since their promulgation and have become obsolete in light of subsequent developments in criminal justice and the introduction of new technologies and managerial techniques in places of detention. The 1990 Regulations were adopted well before the promulgation of the 1997 Criminal Law, the 2012 Criminal Procedure Law, the People’s Police Law, the 1996 Lawyers Law [Lüshi fa] (amended in 2007), and other basic PRC laws. Further, the 1990 Regulations often contradict these laws in both spirit and substance. True to their times, the Regulations tend to be vague, ambiguous, broadly worded, and replete with outmoded terms and politically laden references. For example, "criminal" [renfan] is used instead of the contemporary term "criminal suspect" [fanzui xianyiren], ganjing [sl.: police] is used instead of people's police [renmin jingcha], and "reform through labor" [laodong gaizao] is used instead of prison [jianyu] (Nesossi 2012).

In March 200o, the Bureau for the Management of Prisons and Criminal Detention Centers of the MPS [Gong'an bu jiansuo guanli ju] established a small working group [gongzuo xiaozu] to reform the 1990 Regulations. All major justice-related agencies were consulted in the process. Consultation led to the redrafting of the Regulations, with a revised version including a hundred articles (compared to fifty-two in the 1990 version). In December 2008, the plan to reform the Regulations and to strengthen the supervisory role of the procuratorate was officially inserted in the Central Political Committee Opinions 
on Several Issues on Deepening Reforms of the Judicial System and Working System [Zhongyan zhengfa weiyuanhui guanyu shenhua sifa tizhi he gongzuo jizhi gaige ruogan wenti de yijian] issued by the CCP Central Political Committee (Cheng 2014, 42). These reform priorities were formalized and made public in 2009 in the aftermath of the "Hide and Seek" case. ${ }^{15}$. In that year, reforms to the 1990 Regulations were included in the discussion agenda of the State Council and in the annual session of the NPC (Cheng 2014, 60). Although until that point, legislative reform was intended primarily to be an amendment to the 1990 Regulations, from then on, many scholars started to promote the idea of drafting a new law, the Criminal Detention Law, for NPC promulgation. On January 24, 2011, the proposal for the amendment of the Regulations on Detention Centers drafted by the MPS was submitted to the State Council and, at the time of writing (early 2017), neither the amendment nor the Criminal Detention Law has been passed.

Prisons

Since 1983, prisons have been administered by the Ministry of Justice, which traditionally has been more open than its counterpart that controls most of the other detention facilities in China. Calls for reforms have not been widely discussed in the public sphere and have primarily attracted the attention of prison scholars and officials working within the Chinese penitentiary system (Nesossi and Trevaskes 2016).

The first Prison Law of the PRC was introduced in 1994. A decade later, scholars and officials involved in prison administration around the country started to debate the inadequacies of the legislation and to offer proposals for reform. Reformist voices ask for the Prison Law to be assigned a clearer status in the Chinese legal system (Wang 2002): Critics contend that because the Prison Law was issued by the NPC Standing Committee and not by the NPC itself-the higher legislative organ in the PRC according to the 1982 Constitution and the Legislation Law 2000-it does not have the same authority as the Criminal Law and the Criminal Procedure Law (Cheng et al. 2012) (This means that, in case of conflicting provisions, the criminal legislation would prevail.) Moreover, critics maintain that, in many places, the 1994 Prison Law is inconsistent with other criminal justice legislation. It also lacks specificity with respect to the rights and duties of police guards, management procedures, financial matters, and the administration of punishment within prisons. To strengthen existing legislation, reformers have discussed proposals including the passage of supplementary Regulations on Prison Organization and Regulations on Prison Police, although these proposals have failed to attract significant public attention (Liu et al. 1998).

Seven articles in the 1994 Prison Law were revised in October 2012 to make the legislation consistent with the amended 2012 Criminal Procedure Law. This revision has not attracted particular attention among scholars or the media. It is considered fairly limited in scope and generally unsatisfactory (Han 2013). Prison scholars and officials calling for reforms in the Prison Law had hoped that the new legislation might also improve the institutional structure of prisons and clarify their relations with other institutions and forms of punishment. They have asked for a better system of supervision and improved collaboration with the police, procuratorate, and courts (collectively known as the gongjianfa) and government authorities at the local level responsible for supporting activities related to reform and the social reintegration of those released from prison (Xie 2009). At the time of writing, this process had not begun, and reforms appear to have stalled.

\section{Management of Places of Detention: Labor and Living Conditions}

The management of places of detention has long been a concern in China. This management is crucial to the lives of those who are serving a criminal or administrative sentence, including the provision of

15 The case, generally referred to as the duo mao mao case, concerns an incident in Yunnan Province, in which a detainee died after having been beaten by his fellow cellmates. It sparked outrage because police officers at the detention center sought to explain the death by alleging that it had been accidental, occurring while the detainees were playing a game of hide and seek. 
day-to-day needs, such as food, health care, and drug-withdrawal treatment where needed and the supervision of manual labor, interaction with inmates and personnel, and facilities for routine physical activity. It also regulates the activities of police and justice personnel while at those detention facilities. The very nature of life inside places of detention, because it is barred from the public eye, demands systems for monitoring management practices. Yet analyses of the management of prison and other detention facilities in China are scarce, largely because of the difficulty of accessing documentary sources and even greater difficulty in accessing detention facilities.

Most accounts of the management of prison camps and re-education through labor camps have been produced by Chinese administrative agencies and scholars or by those who have experienced life in prison or re-education through labor camps firsthand. The former literature is highly technical and relatively difficult to access. It analyzes processes of management and suggests needed reforms. The latter literature presents a qualitatively different picture of life in prison. Stories of and from former inmates provide unvarnished accounts of the subsistence economy inside prison walls and, while they still operated, re-education through labor camps.

Through those stories, we learn that, from the 1950s until the late 1980s, the life of detainees in these institutions was marked by extremely long hours working in agricultural fields, in coal mines, or on assembly lines producing cheap goods for export to Western markets. The absence of safety standards meant that all detainees were exposed to the risk of accidents and some were exposed to toxic substances. Particularly in the 1950s, the subsistence economy in prison and re-education through labor camps was such that prisoners/detainees were forced to rely on their agricultural labor to produce their own food, rather than on the state provision of grain, salt, cooking oil, and other necessities. Malnutrition was constant and starvation intermittent ( Wu and Wakeman 1995). By the end of the Cultural Revolution, this trend began to be reversed when authorities allowed prisons and re-education through labor camps to benefit from economic reform policies by selling goods manufactured by inmates in both domestic and international markets. The sale of prisoner-produced goods generated income that contributed to a significant reduction in deaths by starvation. However, it also exacerbated problems of contravening international labor standards and prohibitions on forced labor.

The 1982 Constitution of the People's Republic of China defines labor as a duty of all citizens, including prisoners. But scholars have advocated reconsidering this position on prison labor in the light of accusations that it transgresses various international conventions. Labor performed by detainees of reeducation through labor camps or by addicts detained for compulsory detoxification is not compatible with International Labour Organization Conventions Nos. 29 and 105. Nor is it compatible with provisions of the International Covenant on Civil and Political Rights. (ICCPR) and the International Covenant on Economic, Social, and Cultural Rights. (ICESCR), on the grounds that the performance of this labor is imposed by an administrative, rather than judicial, body ( $\mathrm{Na} \mathrm{2014).}$

Challenges to the camps' management systems have come from other sources and for other reasons. The management of detention facilities by public security organs, which are notoriously resistant to scrutiny, has been implicated in abuses at detention facilities (Wang 2016). Several deaths of people while in police custody or in detention facilities in recent years have highlighted that prisoners are still subject to degrading and dangerous living conditions. Advocates of reform also suggest that administrative rules and regulations seeking to prohibit the practice of torture or inhumane and degrading treatment of prisoners/detainees could be more effective in reducing abuses if the management of detention facilities were transferred from the MPS to the MoJ.

\section{Conclusion}

Simply describing the different forms of detention, both administrative and criminal, is a large and complex task. Setting out the types of activities for which agencies of the Party and the state may deprive people of their liberty shows the extensive range and use of detention. It illustrates not only the wide range of conduct and types of people whom the Party-state views as deserving removal from society but also the perceived utility of detention as a form of social management and control. This article has focused primarily on the changing politics and ideology of detention and on the structure, scope, and reform of detention powers. It has placed less attention on the management of detention 
facilities, not because it is less important but because of space constraints and the comparatively limited amount of published research on this issue.

\section{Ideology and Politics in the Maoist and Reform Eras}

In Part 1, we argued that changed social, economic, and political conditions in the early stages of the reform era produced new forms of crime and increased the rate of offenses. Economic reform has led to a pluralization of interests and values. It has also changed official understandings of crime and dissent and therefore the Party-state's responses to them. In the reform era, the focus has been placed on behavior considered disruptive to the smooth progress of economic modernization needed to underpin economic, social, and political stability. Detention was of practical use to manage both risks and the fear of chaos arising from mass migration among the population as well as the erosion of previous models of social control based on a population that remained in place (Bakken 200o).

Despite the official retreat from class struggle (and suppression of counterrevolutionaries), at the beginning of the reform era, the dichotomy between antagonistic contradictions between "the people" and their "enemies" and non-antagonistic contradictions "among the people" has remained remarkably influential in rationales for punishment and detention. It retains the influence of Mao Zedong's formulation: deal with antagonistic contradictions through suppression and force and deal with nonantagonistic contradictions through education and persuasion. Antagonistic contradictions were traditionally associated with criminal punishment and non-antagonistic contradictions with administrative punishment. However, as this article has illustrated, this link, to the extent that it was ever reflected in practice, has become increasingly tenuous, particularly with the incorporation of some administrative detention powers into the criminal justice system and widespread criticism of some forms of administrative detention as being more punitive and depriving people of their liberty longer than some criminal sanctions do.

All forms of detention combine elements of repression and punishment and purport to reflect the ideals of education and rehabilitation in different measures. They isolate, stigmatize, and traumatize their detainees at the same time as they purport to give them work skills and a new outlook through the consciousness-transforming processes of labor. In this respect as well, the relationship between the rhetoric of education and reform and the reality of punishment is tenuous. The public exposure of systematic abuses in administrative forms of detention, such as detention for repatriation, in places of criminal detention such as kanshousuo, the high levels of relapse of drug users after release from compulsory drug rehabilitation, and the management of all places of detention as sites of labor and production all challenge the claims made about the educational and rehabilitative functions of detention.

\section{Institutional and Legislative Reforms}

Development of the legal system has had far-reaching impact on all forms of deprivation of liberty in China. Law has both prompted and provided the vehicle for the reform of both criminal and administrative forms of detention. It provides the basis for distinguishing between these forms of detention and enables judgments to be made about their legality or illegality. Increasingly, laws impose substantive limits and procedural requirements on the exercise of detention powers as well as on the administration of detention facilities.

The agencies responsible for administering detention have played a central role in debates over reforms of both the criminal and administrative detention powers. People from courts, the police force, prosecution, justice departments, prisons, and legislative bodies are key players in shaping debates and settling legal reforms as representatives of their institutions and as individuals. At stake are institutional influence, power, and resources. The failure to secure legislative authorization of some administrative powers has led to reorganization (e.g., shourong shencha), abolition (e.g., shourong qiansong), or a mixture of both (laodong jiaoyang). State agencies have, through law, shaped the extent of their power, lawful discretion, and the nature and efficacy of oversight mechanisms.

Yet, despite their strategic advantages, institutional actors do not have the legal field entirely to themselves. A small number of reformers and public intellectuals advocate that stronger limits be placed on the use of detention powers. They see limiting or constraining state coercive power, 
especially the powers given to China's public security organs, as the basis for such stability, rather than a threat to stability. They claim that respect for fairness and justice and thus a human rights-based approach to governance lie at the heart of social and political stability. They are critical of the situation in China, where political and institutional considerations about social order and stability underpin and secure the arbitrary powers exercised by public security and other justice organs (Biddulph $2008 \mathrm{a}_{2}$. 2012).

As Nesossi et al. (2016, 163) observed:

This means that while reforms are responsive to political imperatives set by the Party authorities in Beijing, the needs and interests of the institutional powers in the justice system and increasingly, the pressures exercised by individual citizens through civil society organizations and the media, are also forces to be reckoned with.

Viewed positively, the centrality of law in justifying and regulating detention has expanded the range of people able to participate in the processes of drafting legislation and the range of differing viewpoints on policy and regulation of different forms of detention. Viewed negatively, the drafting and interpretation of legislation, law enforcement, and accountability mechanisms remain dominated by the Party and state agencies. The space to use law as a tool to protect the rights of detainees and to hold government agencies to account remains severely constrained.

\section{Reform of Detention Powers: Factors and Impacts}

In this article, we set out factors that we considered relevant to achieving reform of some administrative detention powers. The background conditions are: extensive criticism of the detention power, ongoing and egregious abuse, and problems of illegality. Important considerations are whether the power can be reformed in a way that is politically advantageous or at least not disadvantageous, with limited impacts on social order, and whether other forms of punishment are available if the Party-state still wants to punish that conduct. We saw that the reduction of administrative powers has been achieved in some cases by taking the pragmatic step of expanding the scope of detention in the criminal justice systemthat is, through a partial transfer of detention power from the administrative to the criminal justice system.

We wondered whether the factors relevant to reform of administrative powers were also significant in the reform of criminal detention powers and what other factors might be at play. Certainly, the increasingly tenuous legal status of administrative powers is not replicated in criminal detention powers. One barrier to the reform of criminal detention powers is the difficulty of changing legislation. Another is that many administrative powers have been reformed by transferring the people detained to the criminal justice system. As a result, practical resolutions to problems of abuse and illegality have been achieved by expanding the scope of criminal detention powers. But, as the analysis of criminal detention powers in this article has shown, transferring administrative powers to the criminal system might regularize detention under the Criminal Law and Criminal Procedure Law but does not inevitably result in better protection of the rights of detainees.

So, if criminal detention powers are to be reformed, we might need to look beyond pragmatic questions to consider the impact of ideological commitment to the principles of human rights and, in particular, a commitment to constraining arbitrary detention. Our analysis of both ideological commitments and technical developments in China's version of the rule of law under the Xi regime gives us no reason for optimism.

\section{References}

Amnesty International. 2006. Abolishing "re-education through labour" and other forms of punitive administrative detention: An opportunity to bring the law into line with the International Covenant on Civil and Political Rights. http://www.amnesty.org/en/library/info/ASA17/o16/2006/.

Bakken, Borge. 20oo. The Exemplary Society, Human Improvement, Social Control and the Dangers of Modernity in China, Studies in Contemporary China. New York: Oxford University Press. 
_- - 2005. Introduction: Crime, control and modernity in China. In Crime, Punishment, and Policing in China, ed. Borge Bakken, 1-23. Lanham, MD: Rowman \& Littlefield.

Biddulph, Sarah. 2007a. Legal Reform and Administrative Detention Powers in China. Cambridge: Cambridge University Press.

_—_ 2007b. Social order, prostitution and legal protections of personal liberty in China. In Personal Right and Rule of Law, ed. Jiafu Wang, 158-67. Beijing: Social Sciences Academic Press.

-_- 2008a. The field of crime control and social order. In Examining Practice, Interrogating Theory: Comparative Legal Studies in Asia, ed. Pip Nicholson and Sarah Biddulph, 109-45. Leiden: Martinus Nijhoff.

- _ - 2008b. Prospects for procedural justice reforms in public order regulations in China. Australian Journal of Asian Law 10, no. 1:50-76.

- - - 2012. Between rhetoric and reality: the use of international human rights norms in law reform debates in China. In Narrative and Legal Transfers: Informing Law and Development, ed. John Gillespie and Pip Nicholson, 143-78. Cambridge: Cambridge University Press.

-_— . 2015. The Stability Imperative: Human Rights and Law in China. Vancouver: UBC Press. 2016. What to make of the abolition of re-education through labour? In Legal Reforms and the Deprivation of Liberty in Contemporary China, ed. Elisa Nesossi, Sarah Biddulph, Flora Sapio, and Sue Trevaskes, 23-42. Abingdon, UK: Routledge.

Biddulph, Sarah, and Xie Chuanyu. 2011. Regulating drug dependency in China: the 2008 drug rehabilitation law. British Journal of Criminology 51:978-96.

Boittin, Margaret. 2013. New perspectives from the oldest profession: Abuse and the legal consciousness of sex workers in China. Law E Society Review 47.2:245-278

Chen, Guangzhong, and Xinhua Zeng. 2009. Lun woguo laodong jiaoyang zhidu gaige [Analysis of China's re-education through labor system reforms]. Renmin sifa [People's Judicature] 15:81-83.

Chen, Ruihua. 2003. Laodong jiaoyang de lishi kaocha yu fansi [Study and rethinking of the history of re-education through labor]. In Zhi'an guanli zhidu sicun [Reflection on the Regulation of Public Order], ed. Weiguo Zhu, 79-126. Beijing: Falü chubanshe.

-_- 2004. Wei jue jiya zhidu de shizheng yanjiu [An Empirical Study of the System of Pretrial Detention]. Beijing: Beijing daxue chubanshe.

Chen, Weidong. 2005. Jiaya zhidu yu renmin renquan baozheng [The System of Detention and Protection of Human Rights]. Beijing: Zhongguo jiancha chubanshe.

Chen, Xingliang. 2oo1a. Laodong jiaoyang: genju guoji renquan gongyue zhi fenxi [Re-education through labor: Analysis with reference to international human rights covenants]. Faxue [Law Science], 10:49-52.

___ 20o1b. Laodong Jiaoyang: genju guoji renquan gongyue zhi fenxi [Research on China's system of re-education through labor: From the perspective of criminal rule of law]. Zhongwai faxue [Peking University Law Journal] 13, no. 6:689-700.

Chen, Zaishang, and Xiangqian Cui. 20o8. Laodong jiaoyang zhidu de sanwei quexian yu chongsu [Three-dimensional defects and remodeling of the system of re-education through labor]. Tiedao jingguan gaodeng zhuanke xuexiao xuebao [Journal of Railway Police College] 4:32-38.

Chen, Zexian. 2004. Shourong jiaoyang zhidu ji qi gaige [The system of detention for education and its reform]. http://www.iolaw.org.cn/showArticle.asp?id=998/.

Chen, Zexian, Wenren Liu, Xuewu Qu, and Rui Feng. 2002. Guanyu laodong jiaoyang zhidu de yanjiu baogao [Research report on the system of re-education through labor]. In Lixing yu chengxu: zhongguo laodong jioyang zhidu yanjiu [Rationality and Order: Research on China's System of Re-Education through Labor], ed. Huaizhi Chu, Xingliang Chen, and Shaoyan Zhang, 331-43. Beijing: Falü chubanshe.

Cheng, Keqiang, Yan Yongsheng, and Yan Ximei. 2012. Jianyufa xiugai wanshanzhi sikao [Considerations on amending and perfecting the prison law]. Fanzui yu gaizao yanjiu [Research on Crime and Punishment] 6:18-22.

Cheng, Lei. 2014. Kanshousuo lifa wenti yanjiu [Research Questions on Legislation Relating to Detention Houses]. Beijing: Zhongguo fazhi chubanshe.

2016. Zhiding jusuo jianshe juzhu shishi wenti de jieshilun fenxi [Analysis on the interpretative theory on implementing surveillance at a designated place of residence]. Zhongguo faxue [China Legal Science] 3:226-43. 
Cheng, Lei and Elisa Nesossi. 2016. China's pre-trial detention centres: challenges and opportunities for reform. In Legal Reforms and Deprivation of Liberty in Contemporary China, eds., Elisa Nesossi, Sarah Biddulph, Flora Sapio and Susan Trevaskes, 95-111. London and New York: Routledge.

CNTV [China National Television]. 2013. Quanguo zhengfa gongzuo huiyi: laojiao zhidu jinnian ni tingzhi shiyong [National political-legal committee meeting: Intends to stop using reeducation through labor this year]. January 8. Chu, Huaizhi, Xingliang Chen, and Shaoyan Zhang, ed. 2002. Lixing yu chengxu: zhongguo laodong jiaoyang zhidu yanjiu [Rationality and Order: Research on China's System of Re-Education through Labor]. Beijing: Falü chubanshe.

Clarke, Donald, and James Feinerman. 1995. Antagonistic contradictions: criminal law and human rights in China. China Quarterly, no. 141:135-54.

Congressional Executive Committee on China. 2013. Prospects for reforming China's re-education through labor system. May 9. https://www.cecc.gov/publications/issue-papers/prospects-forreforming-chinas-reeducation-through-labor-system/.

Cui, Qingxin, and Liu Yizhan. 2013. Zhongguo jiang tuijin laojiao, huji deng zhidu gaishan [China will promote reform of re-education through labor, household registration and other systems]. Xinhua net, January 7. http://www.chinanews.com/fz/2013/o1-07/4467425.shtml

Dan, Wei. 2012. Lun renmin jianchayuan jiansuo jiancha gongzuo gaige [A discussion on reforms to the procuratorate supervision of detention]. Henan shehui kexue [Henan Sociology] 12:9.

Dong, Gaoqun. 2002. Laodong jiaoyang zhidu yinggai feizhi [The re-education through labor system should be abolished]. Renmin daibiao bao [People's Representatives Newspaper], December 5:3.

Dui Hua. 2010. Professors Yu Jianrong and Jiang Ming'an spar over future of re-education through labor. Dui Hua Human Rights Journal, July 9, http://www.duihuahrjournal.org/2010/o7/professorsyu-jianrong-and-jiang-mingan.html.

Dutton, Michael R. 1992. Policing and Punishment in China: From Patriarchy to the People. Cambridge: Cambridge University Press.

-_ - 2005. Policing Chinese Politics. Durham: Duke University Press.

Dutton, Michael and Xu Zhangrun. 1998. Facing difference: Relations, change and the prison sector in contemporary China. In Comparing prison systems: Toward a comparative and international penology, ed. Robert Weiss and Nigel South Amsterdam, Gordon and Breach Publishers.

Dutton, Michael, and Xu Zhangrun. 2005. A question of difference: the theory and practice of the Chinese prison. In Crime, Punishment and Policing in China, ed. Børge Bakken, 103-40. Lanham, MD: Rowman \& Littlefield.

Editorial Committee. PRC Administrative Punishments Law Explanation and Cases. 1996. Zhonghua renmin gongheguo xingzheng chufa fa shiyi yu anli [PRC Administrative Punishments Law Explanation and Cases]. Beijing: Renmin fayuan chubanshe.

Fan, Bin. 2009. Xianxing laodong jiaoyang zhidu cunzai de zhuyao wenti he gaige gouxiang [Current problems of re-education through labor system and proposal for its reforms]. Shanxi gaodeng xuexiao shehui kexue xuebao [Social Sciences Journal of Colleges of Shanxi] 21, no. 12:83-86.

Feng, Ruirui, Yanhai Liu, and Ying Dai. 2008. Lun feichu laodong jiaoyang zhidu de biyaoxing [Discussing the necessity of abolishing re-education through labor]. Fazhi yu shehui [Legal System and Society] 18:246.

Fu, Hualing. 2005a. Punishing for profit. profitability and rehabilitation in a laojiao institution. In Engaging the Law in China. State, Society, and Possibilities for Justice, ed. Neil J. Diamant, Stanley Lubman, and Kevin J. O’Brien, 213-29. Redwood City, CA: Stanford University Press.

——_. 2005b. Re-education through labor in historical perspective. China Quarterly, no. 184:811-31.

——. 2009. Dissolving laojiao. China Rights Forum 1:54-58.

Gao, Qiang. 2011. Guowuyuan jiedu tiaoli sui dabu chuangxin dan xiaoqu dongtai guankong reng yaoyao wu [Despite the big innovation in the state council's drug prohibition regulations, abolition of dynamic control is still remote]. July 21. http://bbs.tianya.cn/post-news-217161-1.shtml

Guo, Zhiyuan. 2016. Deprivation of liberty against one's will in mental health institutions in contemporary China? In Legal Reforms and the Deprivation of Liberty in Contemporary China, ed. Elisa Nesossi, Sarah Biddulph, Flora Sapio, and Susan Trevaskes, 62-76. Abingdon, UK: Routledge.

Han, Shuqin. 2013. "Jianyu fa” xiugai ying zhu zhong jiejue de ruogan wenti [Several major problems that needed to be solved in the revision of the "prison law"]. Henan sifa jingguan zhiye xueyuan xuebao [Journal of Henan Judicial Police Vocational College] 11, no. 1:27-29. 
Hand, Keith 2006-7. Using Law for a Righteous Purpose: The Sun Zhigang Incident and Evolving Forms of Citizen Action in the People's Republic of China Columbia Journal of Transnational Law 45: 114-195

Henriot, Christian. 1995. "La fermature": The abolition of prostitution in Shanghai, 1949-58. China Quarterly, no. 142:467-86.

Herschatter, Gail. 1997. Dangerous Pleasures: Prostitution and Modernity in Twentieth-Century Shanghai. Berkeley: University of California Press.

$\mathrm{Hu}$, Weilie. 2003. Laodong jiaoyang zhidu ying yu feichu [The system of re-education through labor should be abolished]. In Zhi'an guanli zhidu sicun [Reflections on the Public Order Regulation], ed. Weiguo Zhu, 136-47. Beijing: Falü chubanshe.

$\mathrm{Hu}$, Xingdou, Renwen Liu, Zhu Shunzhong, and He Xiaopeng. 2007. Shiyue tan: laojiao zhidu de hefaxing weiji [October talks: The crisis in legitimacy of the system of re-education through labor]. Xin shiji zhoukan [New Century Weekly] 31:64-67.

Huang, Cary. 2013. Legal reforms a "litmus test" of Xi Jinping's commitment to change. South China Morning Post, January 9.

Human Rights in China. 2001. Re-education through Labor [RTL]: A Summary of Regulatory Issues and Concerns. Hong Kong: Human Rights in China.

Human Rights Watch. 2002. Dangerous Meditation: China's Campaign against Falungong. New York: Human Rights Watch. https://www.hrw.org/reports/2002/china/.

Hung, Veron Meiying. 2002. Improving human rights in China: Should re-education through labor be abolished? Columbia Journal of Transnational Law 41:303-26.

- - 2003. Reassessing re-education through labour. China Rights Forum 2:35-41.

Jeffreys, Elaine. 2004. China, Sex and Prostitution. London: Routledge.

Keith, Ronald. 1994. China's Struggle for the Rule of Law. London: St. Martin's Press.

Kiely, Jan. 2014. The Compelling Ideal: Thought Reform and the Prison in China, 1901-1956. New Haven: Yale University Press.

Li, Baozhen. 1999. Dangqian gong'an zhefa zhong cunzai de zhuyao wenti ji duice zhengwen zongshu [Summary of solicited articles on the main problems and counter-measures existing in current public security enforcement]. Gong'an yanjiu [Public Security Studies] 2, no. 64:19-21.

Li, Enshen. 2016. China's socialization of administrative offenders in the community: An unrealistic agenda? In Legal Reforms and the Deprivation of Liberty in Contemporary China, ed. Elisa Nesossi, Sarah Biddulph, Flora Sapio, and Susan Trevaskes, 43-61. Abingdon, UK: Routledge

Liu, D. 2012. Lun woguo xingfazhong de xianzhi jianxing [On the restriction of commutation in China's criminal law]. Zhengfa luncong [Debates in Politics and Law] 1:111-16.

Liu, Jingying, Fang Zhi, and Zheng Leize. 1998. Zhiding jianyufa shishi tiaoli wanshan jianyufa tizhi [Enacting the implementing regulations on the prison law to perfect the system of prison legislation]. Zhongguo sifa [China Judiciary] 9:6.

Liu, Jinpeng. 2005. You gao fuxilü dui woguo xianxing jiedu tixi de sikao [Considering China's drug rehabilitation system from the perspective of the high relapse rate]. Fanzui yu gaige yanjiu [Crime and Reform Research] 7: 24. Liu, Renwen. 1998. Laodong jiaoyang ji xu lifa [Reeducation through labor urgently needs legislation]. Faxue zazhi [Legal Studies Journal] 5:2223.

_- _ 2001. Laodong jiaoyang zhidu jiqi gaige [The re-education through labor system and its reform]. Xingzheng faxue yanjiu [Administrative Law Studies] 4:13-21.

Ma, Weigang, ed. 1993. Jinchang jindu: jianguo chuqi de lishi huigu [Prohibition of Prostitution and Drugs: A Historical Review of the Early Period in Establishing China]. Beijing: Jingguan xueyuan jiaoyu chubanshe.

Macbean, Nicola. 2016. Addressing the "hide and seek" scandal: Restoring the legitimacy of kanshousuo. In Legal Reforms and the Deprivation of Liberty in Contemporary China, ed. Elisa Nesossi, Sarah Biddulph, Flora Sapio, and Susan Trevaskes, 112-30. Abingdon, UK: Routledge.

McConville, Mike, Satnam Choongh, Pinky Choy Wan, Dick Hong, Eric Chui Wing, Ian Dobinson, and Carol Jones, ed. 2011. Criminal Justice in China: An Empirical Enquiry. Cheltenham, UK: Edward Elgar.

Mou, Yuchuan. 2013. He Xuefeng: Feichu laojiao zhidu, tian ye bu hui ta xialai [He Xuefeng: The day reeducation through labor is abolished, the sky will not fall]. Jimen juece [Forum], October 21.

Mühlhahn, Klaus. 2009. Criminal Justice in China: A History. Cambridge: Harvard University Press. 
Munro, Donald J. 1977a. Belief control: The psychological and ethical foundations. In Deviance and Social Control in Chinese Society, ed. Amy Auberacher Sidney Wilson, Leonard Greenblatt, and Richard Whittingham Wilson, 14-36. New York: Praeger.

- - 1977b. The Concept of Man in Contemporary China. Ann Arbor: University of Michigan Press.

Munro, Robin. 200o. Judicial psychiatry in China and its political abuses. Columbia Journal of Asian Law 14, no. 1:1-128.

-_- 2007. China's Psychiatry Inquisition: Dissent, Psychiatry and the Law in Post-1949 China. London: Wildy, Simmonds and Hill.

Na, Jiang. 2014. China and International Human Rights. Harsh Punishment in the Context of the International Covenant on Civil and Political Rights. Dordrecht: Springer.

Nesossi, Elisa. 2012. China's Pre-Trial Justice: Criminal Justice, Human Rights and Legal Reforms in Contemporary China. London: Wildy, Simmonds and Hill.

_-_ 2014. Detention, stability and "social management innovation." In The Politics of Law and Stability in China, ed. Susan Trevaskes, Elisa Nesossi, Flora Sapio, and Sarah Biddulph, 219-43. Cheltenham, UK: Edward Elgar.

Nesossi, Elisa, and Susan Trevaskes. 2016. Framing imprisonment studies in China: ideology, law and politics. In Legal Reforms and the Deprivation of Liberty in Contemporary China, ed. Elisa Nesossi, Sarah Biddulph, Flora Sapio, and Susan Trevaskes, 133-144. Abingdon, UK: Routledge.

Nesossi, Elisa, Sarah Biddulph, Flora Sapio, and Susan Trevaskes. 2016. Opportunities and challenges for legislative and institutional reform of detention in China. In Legal Reforms and the Deprivation of Liberty in Contemporary China, ed. Elisa Nesossi, Sarah Biddulph, Flora Sapio, and Susan Trevaskes, 162-70. Abingdon, UK: Routledge.

Peerenboom, Randall 2003. Out of the pan and into the fire: Well-intentioned but misguided recommendations to eliminate all forms of administrative detentions in China. Northwestern University Law Review 98:991-1000.

Potter, Pitman. 2003. Belief in control: Regulation of religion in China. China Quarterly, no. 174:317-37.

Qi, Dan. 2008. Zhi'an zhixu guanli zhuanlun [Special Discussion of the Management of Public Order Administration]. Beijing: Zhongguo renmin gong'an daxue chubanshe.

Ren, Enshun. 1992. Laodong jiaoyang de wenti yu chulu [The problems and prospects for re-education through labor]. Gong'an yanjiu [Public Security Studies] 2, no. 22:12-16.

Rosenzweig, Joshua. 2014. Public opinion, criminal justice, and incipient popular liberalism in China. In The China Story Journal. https://www.thechinastory.org/2014/o3/public-opinion-criminaljustice-and-incipient-popular-liberalism-in-china/.

_- _ 2016. Residential surveillance: Evolution of a Janus-faced measure. In Legal Reforms and the Deprivation of Liberty in Contemporary China, ed. Elisa Nesossi, Sarah Biddulph, Flora Sapio, and Sue Trevaskes, 79-94. Abingdon, UK: Routledge.

Rosenzweig, Joshua, Flora Sapio, Jiang Jue, Teng Biao, and Eva Pils. 2013. Comments on the 2012 revision of the Criminal Procedure Law. In Comparative Perspectives on Criminal Justice in China, ed. Mike McConville and Eva Pils, 455-503. Cheltenham, UK: Edward Elgar.

Sapio, Flora. 2008. Shuanggui and extralegal detention in China. China Information 22, no. 1:7-37.

- - 2010. Sovereign Power and the Law in China. Boston: Brill.

Seymour, James D., and Richard Anderson. 1998. New Ghosts, Old Ghosts. Prison and Labor Reform Camps in China. Armonk, NY: M.E. Sharpe.

Song, Yinghui. 2007. Xingshi susong fa [Criminal Procedure Law]. Beijing: Tsinghua daxue chubanshe.

Sun, Lianzhong. 2007. Xingshi qiangzhi cuoshi yanjiu [Analysis of the Criminal Coercive Measures]. Beijing: Zhishi changquan chubanshe.

Tanner, Murray Scot. 200o. State coercion and the balance of awe: The 1983-1986 "stern blows" anticrime campaign. China Journal 44:93-125.

-_- 2005. Campaign-style policing in China and its critics. In Crime, Punishment, and Policing in China, ed. Borge Bakken, 171-88. Lanham, MD: Rowman \& Littlefield.

Trevaskes, Susan. 2007. Courts and Criminal Justice in Contemporary China. Lanham, MD: Lexington Press.

-_ 2010. Policing Serious Crime in China: From "Strike Hard" to "Kill Fewer." London: Routledge.

- _ 2013. China's death penalty: The Supreme People's Court, the suspended death sentence and the politics of penal reform. British Journal of Criminology 53, no. 3: 482-99.

_- 2016. Politico-legal discourse in punishing crime: using Mao to package the people's war on terror, harmonious justice and stability maintenance. The China Quarterly 226: 299-318. 
United Nations, Commission on Human Rights. 2004. Civil and Political Rights, Including the Questions of Torture and Detention. Report of the Working Group on Arbitrary Detention. Mission to China, E/CN.4/2005/6/Add.4, https://documents-ddsny.un.org/doc/UNDOC/GEN/Go5/102/74/PDF/Go510274.pdf?OpenElement

United Nations, Commission on Human Rights. 2006. Civil and Political Rights, Including the Question of Torture and Detention. Report of the Special Rapporteur on Torture and Other Cruel, Inhuman or Degrading Treatment or Punishment, Manfred Nowak. Mission to China, E/CN4/2006/6/Add6, https://documents-ddsny.un.org/doc/UNDOC/GEN/Go6/117/5o/PDF/Go61175o.pdf?OpenElement

Wang, Faqiang. 1997. Tan laodong jiaoyang zhidu de cunfei [Discussing preservation or abolition of reeducation through labor]. Faxue zazhi [Legal Studies Journal] 4:32.

Wang, Maya. 2016. Dispatches: China should end deaths in police custody. Human Rights Watch, May 27, https://www.hrw.org/news/2016/05/27/dispatches-china-should-end-deaths-policecustody/.

Wang, Wei. 2015. Huang Haibo piaochang shijian nuzhuren liuxinyu yu yishen huoaxing 6 ge yue [Huang Haibo prostitution case mistress Liu Xinyu sentenced at first instance to 6 months' imprisonment]. news.qq.com, May 12.

Wang, Zhiliang. 2002. Jianyufa yin shengge wei jibenfa [The prison law ought to be upgraded to a basic law]. Anhui jingcha zhiye xueyuan xuebao [Journal of the Anhui Police Training College] 1, no. 2:29-31.

Wu, Hongda Harry, and Caroline Wakeman. 1995. Bitter Winds: A Memoir of My Years in China's Gulag. New York: Wiley. Xia, Chongsu, ed. 2001. Laodong jiaoyang zhidu gaige wenti yanjiu [Research on the Reform of Re-education through Labor]. Beijing: Falü chubanshe.

Xie, Liping. 2009. Guanyu "jianyufa" xiugai he wanshan de sikao [Reflections on the revision and perfection of the "prison law"]. Zhongguo sifa [Justice of China] 2:23-5.

Xinhua. 2016. Criteria clarified for capital punishment in graft cases. 18 April, at: http://Www.China.Org.Cn/China/2016-04/18/Content_38267461.Htm

Yang, Cheng. 20o8. Balancing the needs in the reform of labor re-education. In Zhongguo laodong jiaoyang zhidu de jiantao yu gaige [Re-Assessing and Reforming the Labor Re-Education System in China], ed. Bingzhi Zhao and Cheng Yang, 1-23. Beijing: Zhongguo renmin gong'an daxue chubanshe.

Zhang, Chuanwei. 2009. Cong ganga, dianfu zouxiang xinsheng: laodong jiaoyang gaizao wei shequ jiaozheng zhi fenxi [From embarrassment and subversion to rebirth: An analysis of the reform of re-education through labor to community corrections]. Beijing xingzheng xueyuan xuebao [Journal of Beijing Administrative College] 1:80-85.

Zhang, Jinya, and Ziwen Liu. 2014. Huang Haibo shourong qiman huoshi [Huang Haibo released after his period of detention expires]. People's Daily Online, December 1. http://legal.people.com.cn/n/2014/1201/c42510-26121742.html.

Zhang, Minfa. 20o8. Guanyu laodong jiaoyang zhidu jiben wenti de sikao [Reflections on the fundamental issues of the system of re-education through labor in China]. Zhengfa xuekan [Journal of Political Science and Law], 6:56-6o.

Zhou, Yan. 1999. Woguo laodong jiaoyang zhidu gaige chuyi [Proposals for reform of my country's reeducation through labor system]. Zhongguo xingshifa zazhi [China Criminal Science] 42, no. 6:21-27. 


\section{University Library}

\section{- M M I N E R VA A gateway to Melbourne's research publications}

Minerva Access is the Institutional Repository of The University of Melbourne

Author/s:

Biddulph, S;Nesossi, E;Sapio, F;Trevaskes, S

Title:

Detention and Its Reforms in the PRC

Date:

2017

Citation:

Biddulph, S., Nesossi, E., Sapio, F. \& Trevaskes, S. (2017). Detention and Its Reforms in the PRC. China Law and Society Review, 2 (1), pp.1-62. https:// doi.org/10.1163/25427466-00201001.

Persistent Link:

http://hdl.handle.net/11343/252820 